\title{
MERCADO FUTURO DO AÇÚCAR DA BM\&F: INFLUÊNCIA DOS CROSS HEDGES E DA TAXA DE JUROS
}

\author{
Paulo Henrique Galleguillos Calderon \\ Bacharel em Ciências Econômicas
}

Orientadora: Prof ${ }^{\circledR}$ Dra. HELOISA LEE BURNQUIST

Dissertação apresentada à Escola Superior de Agricultura "Luiz de Queiroz", Universidade de São

Paulo, para obtenção do título de Mestre em

Ciências, Área de Concentração: Economia Aplicada.

PIRACICABA

Estado de São Paulo - Brasil

Abril - 2001 
Dados Internacionais de Catalogação na Publicação (CIP) DIVISĀO DE BIBLIOTECA E DOCUMENTAÇĀO - Campus "Luiz de OueirOz"/USP

Galleguillos Calderon, Paulo Henrique

Mercado futuro do açúcar da BM\&F: influência dos cross hedges e da taxa de juros / Paulo Henrique Galleguillos Calderon. - - Piracicaba, 2001.

$87 \mathrm{p}$.

Dissertação (mestrado) - Escola Superior de Agricultura Luiz de Queiroz, 2001. Bibliografia.

1. Açúcar 2. Bolsa de futuros 3. Bolsa de mercadorias 4. Mercado futuro 5. Taxa de juro I. Título

CDD 338.476641

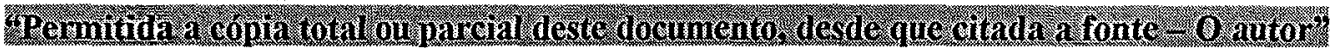


“...Depois que a experiência me ensinou que tudo aquilo que acontece na vida comum são coisas vãs e fúteis, e quando percebi que todas as coisas que eu temia e que me temiam nada tinham de bom ou mau, a não ser o grau em que a mente era por elas afetada, decidi, por fim investigar se havia alguma coisa que pudesse ser verdadeiramente boa e capaz de comunicar a sua bondade e pela qual a mente pudesse ser afetada a ponto de excluir todas as outras coisas; decidi investigar se podia descobrir e obter a faculdade de gozar, por toda a eternidade, uma contínua felicidade suprema..."

“...Descobri que só o conhecimento é poder e liberdade; e a única felicidade permanente é a busca do conhecimento e a alegria da compreensão..."

(Baruch Sprnóza, 1663 )

Ao meu pai, Arnaldo, e à minha mãe, Penha. Dedico. 


\section{AGRADECIMENTOS}

À Deus pela infinita grandeza, o qual com seu amor absoluto me deu capacidade, força e condições fisica e espiritual para vencer mais uma etapa da minha vida.

Aos meus pais, por todo apoio, dedicação, carinho e confiança, aos quais serei eternamente grato.

Aos meus irmãos Júnior, Lílian e Arturo pela confiança, carinho e aposta constante em minha pessoa.

À minha família que, de uma forma ou de outra, contribuiu ao longo da minha vida para o meu desenvolvimento, principalmente pessoal.

À Professora Heloisa, pela orientação com extrema competência, confiança, paciência e principalmente amizade demonstrados durante todo o curso. Conjunto de atributos bastante nobres que muito contribuiu para o meu aprendizado e desempenho.

Aos professores do Departamento de Economia, Administração e Sociologia da ESALQ-USP. Em especial aos Professores Geraldo, Mírian e Pedro Mello pela atenção, prestatividade e sugestões para o presente trabalho.

Aos funcionários do Departamento de Economia, Administração e Sociologia da ESALQ-USP, pela atenção e dedicação demonstradas em todos os momentos. Em especial à Maielli, Lu e Ligiana.

À USP e à CAPES, que ofereceram suporte necessário para o bom aproveitamento do curso de Pós-graduação.

Aos amigos do mestrado e doutorado que fizeram a minha estadia em Piracicaba extremamente agradável: Fabiano, Leopoldo, Bruno, Fábio, Fabiana, Juliana, Clailton, Expedito, Eraldo, Pacheco, Daltro, Carlinha, Cris, Dani e tantos outros que a falta de espaço me impede de citar, mas que sempre terão lugar em minhas melhores lembranças.

Aos amigos de Piracicaba com os quais dividi momentos de esgotamento, alegrias, etc.: Marilza e Gaúcho.

À Mayra pelo companheirismo, atenção e compreensão que foram sem dúvida muito importantes nessa fase da minha vida.

Ao pessoal do Banco HSBC pela amizade e incentivo constantes que indiretamente me deram forças nessa etapa. Em especial: Salvador, Rubem, Rô, Edson, Zé Carlos e Filipe. 


\section{SUMÁRIO}

Página

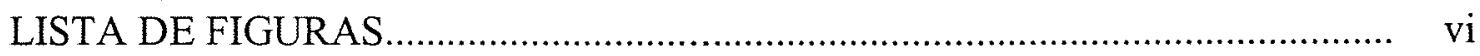

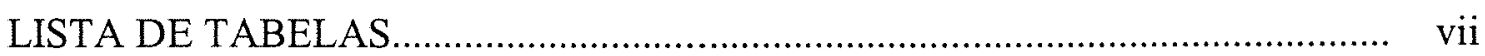

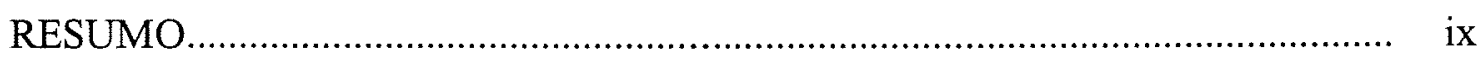

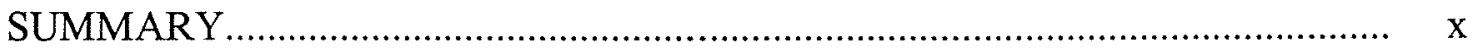

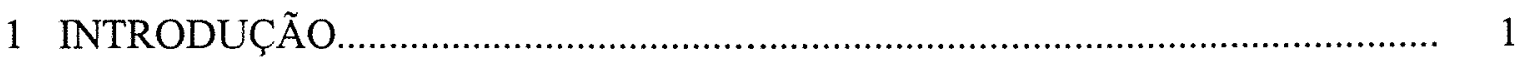

1.1 Considerações Gerais........................................................................................

1.2 O Enfoque da Pesquisa.................................................................................. 3

1.2.1 Cross Hedge, Eficiência de Mercado e Eficiência de Hedge..................... 4

1.2.2 A Taxa de Juros e a Own Rate................................................................. 8

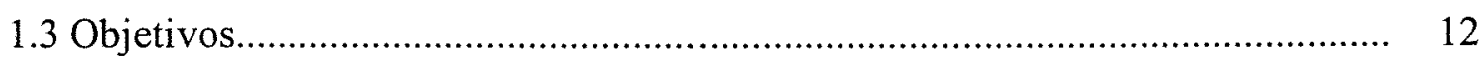

2 O SETOR SUCROALCOOLEIRO NO BRASIL ................................................ 14

2.1 Crescimento e Principais Crises do Setor Açucareiro Brasileiro......................... 14

2.2 Intervenção Governamental no Setor Açucareiro................................................ 17

2.3 Desregulamentação do Setor Sucroalcooleiro.................................................... 21

2.4 O Contrato Futuro Cambial do Açúcar da BM\&F............................................. 23

3 MERCADOS FUTUROS DE COMMODITIES AGRÍCOLAS.............................. 24

3.1 Importância Econômica dos Mercados Futuros de Commodities Agrícolas........ 24

3.2 Eficiência de Mercado versus Eficiência de Hedge............................................ 28

3.3 Cross Hedging e Risco Residual Relativo.......................................................... 31

3.4 Gerenciamento do Risco de Preço e Razão de Hedge ........................................... 33

3.5 Taxa de Juros e Custos de Carregamento......................................................... 35 


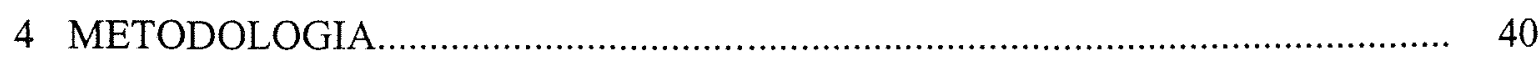

4.1 Análise da Eficiência de Mercado................................................................. 40

4.2 Comparação da Eficiência de Hedge na BM\&F, CSCE e na LIFFE.................. 46

4.3 Risco Residual Relativo.................................................................................. 51

4.4 Grau de Associação entre o Diferencial Taxa de Juros e Taxa Própria e o

Volume de Negociação do Contrato Futuro Cambial do Açúcar da BM\&F...... 55

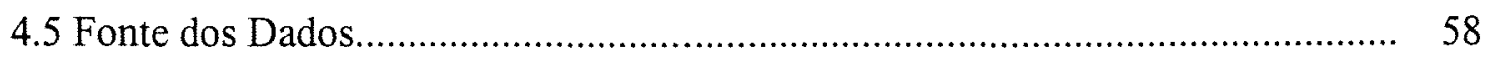

5 RESULTADOS E DISCUSSÃO.

5.1 Eficiência dos Mercados Futuros................................................................... 60

5.1.1 Características das Séries de Preços..................................................... 61

5.1.2 Testes de Co-integração para Eficiência de Mercado................................ 62

5.2 Estimativa da Eficiência de Hedge na BM\&F, CSCE e na LIFFE...................... 71

5.3 Cross Hedge e Risco Residual Relativo - Resultados...................................... $\quad 72$

5.4 Taxa de Juros, Taxa Própria e o Volume de Negociação do Contrato Futuro

Cambial do Açúcar na BM\&F....................................................................... $\quad 75$

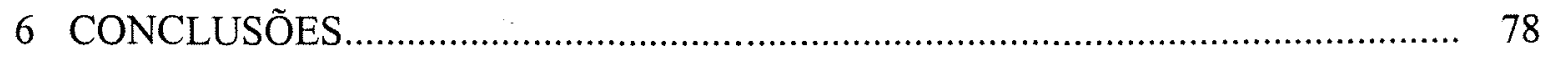

7 REFERÊNCIAS BIBLIOGRÁFICAS …...................................................... 81

ANEXO 


\section{LISTA DE FIGURAS}

\section{Página}

1 Taxas de Juros Nominais Anualizadas da Selic Mensal- Jan/95 - Jun/99

2 Volume de Negócios do Contrato Futuro Cambial do Açúcar Cristal na BM\&F.....

3 Comportamento dos Preços do Açúcar no Mercado Disponível Brasileiro e Mercado Futuro da BM\&F ( $1^{\circ}$ vencimento). Médias Semanais. Período: $14 / 04 / 1997$ à 28/07/2000

4 Comportamento dos Preços do Açúcar no Mercado Disponível Brasileiro e Mercado Futuro da CSCE ( ${ }^{\circ}$ vencimento). Médias Semanais. Período: 14/04/1997 à 28/07/2000

5 Comportamento dos Preços do Açúcar no Mercado Disponível Brasileiro e Mercado Futuro da LIFFE ( ${ }^{\circ}$ vencimento). Médias Semanais. Período: $14 / 04 / 1997$ à 28/07/2000

6 Taxa de Juros de Mercado e a Taxa de Remuneração do Açúcar Brasileiro na BM\&F. Período: 14/04/1997 à 28/07/2000 


\section{LISTA DE TABELAS}

\section{Página}

1 Evolução Industrial do Açúcar no Brasil - Número de Engenhos............................ 15

2 Volume de Açúcar Exportado, 1901-1923......................................................... 16

3 Volume de Açúcar Exportado, 1930-1969.......................................................... 19

4 Evolução da Produção e Exportação de Açúcar no Brasil - 1988/89 a 1998/99....... 22

5 Mercados de own hedge e de cross hedges selecionados....................................... 53

6 Teste de raiz unitária: Média Semanal do Indicador de Preço de Açúcar Cristal ESALQ/BM\&F (S); Cotações do Mercado Futuro de Açúcar da BM\&F (FB), da $\begin{array}{lllllll}\text { CSCE } & (F C) ; \quad \text { e da LIFFE } & (F L) \text {. Período: 14/04/1997 a }\end{array}$ $28 / 04 / 2000$.

7 Regressões de Co-integração. Média semanal do Indicador de Preço de Açúcar Cristal ESALQ/BM\&F $(S)$ e Cotações do Mercado Futuro de Açúcar da BM\&F (FB). Período: 14/04/1997 a 28/04/2000 
8 Regressões de Co-integração. Estacionariedade dos resíduos. Média Semanal do Indicador de Preço de Açúcar Cristal ESALQ/BM\&F $(S)$ e Cotações do Mercado Futuro do Açúcar da BM\&F $(F B)$. Período: 14/04/1997 a $28 / 04 / 2000$.

9 Regressões de Co-integração. Média Semanal do Indicador de Preço de Açúcar Cristal ESALQ/BM\&F ( $S$ ) e Cotações do Mercado Futuro de Açúcar da CSCE $(F C)$. Período: 14/04/1997 a 28/04/2000.

10 Regressões de co-integração. Estacionariedade dos Resíduos. Média Semanal do Indicador de Preço de Açúcar Cristal ESALQ/BM\&F (S) e Cotações do Mercado Futuro do Açúcar da $\operatorname{CSCE}(F C)$. Período: 14/04/1997 a $28 / 04 / 2000$

11 Regressões de Co-integração. Estacionariedade dos resíduos. Média Semanal do Indicador de Preço de Açúcar Cristal ESALQ/BM\&F $(S)$ e Cotações do Mercado Futuro do Açúcar da CSCE $(F C)$. Período: 14/04/1997 a $28 / 04 / 2000$

12 Estimativa do Modelo de Eficiência de Hedge do Mercado Futuro do Açúcar nas Bolsas BM\&F, CSCE E LIFFE. Período analisado: 14/04/1997 à 28/07/2000.

13 Estimativas da Variável Risco Residual Relativo $\left(R R_{i}\right)$ considerando Relações de Operações de Hedge Direto (BM\&F) e Cross Hedges (CSCE ou LIFFE). Período: $14 / 04 / 1997$ a $28 / 07 / 2000$

14 Estimativa da Correlação entre o Volume de Contratos em Aberto $(V)$ e o Diferencial $(d)$ entre a Taxa Própria do Açúcar e a Taxa de Juros. Período: 14/04/1997 à 28/07/2000 


\title{
MERCADO FUTURO DO AÇÚCAR DA BM\&F: INFLUENCIA DOS CROSS HEDGES E DA TAXA DE JUROS
}

\author{
Autor: Paulo Henrique Galleguillos Calderon \\ Orientadora: Prof ${ }^{a}$ Dra. Heloisa Lee Burnquist
}

\section{RESUMO}

Nesse trabalho busca-se identificar e analisar fatores que podem ter-se constituído em restrições à utilização mais intensa do contrato de futuros de açúcar da BM\&F desde o seu lançamento, em setembro de 1995 até julho de 2000. A pesquisa foi conduzida empregando-se um conjunto de procedimentos para a realização de análises quantitativas, tanto no contexto microeconômico quanto no âmbito macroeconômico. Os procedimentos utilizados foram selecionados junto à literatura relacionada por se apresentarem adequados ao propósito da presente pesquisa.

A investigação é feita abordando aspectos tais como: (i) análise do grau com que esse mercado futuro vem sendo eficiente, para o hedger brasileiro, em fornecer previsões não viesadas dos preços spot; (ii) análise da Eficiência de Hedge, ou seja, como o Mercado Futuro da BM\&F é eficiente em proporcionar proteção contra o risco de variação não esperada de preço, relativamente aos principais Mercados Futuros de Açúcar de expressão internacional: CSCE (Nova Iorque) e LIFFE (Londres); (iii) influência dos cross hedges sobre o montante transacionado do contrato brasileiro; e (iv) verificação de como a variação da taxa de juros pode influenciar o volume de negócios do Contrato Futuro Cambial do Açúcar da BM\&F.

De forma geral, conclui-se que não se pode afirmar que a existência de mercados futuros internacionais alternativos tenham sido um empecilho para a utilização mais ampla desse instrumento brasileiro de gerenciamento de risco de preço. 


\title{
BM\&F SUGAR FUTURES CONTRACTS VIABILITY: CROSS HEDGES ANALYSIS AND INTEREST RATES APPROACH
}

\author{
Author: Paulo Henrique Galleguillos Calderon \\ Adviser: Prof. Heloisa Lee Burnquist
}

\section{SUMMARY}

The purpose of this work was to identify factors that may been restricted the intensity by which the Sugar BM\&F Futures Contracts was used by Brazilian hedgers, as well as to evaluate their relative importance, considering the period since the contract was introduced, from September 1995, until July 2000. The research was conducted based on a set of procedures that allowed for quantitative analysis, considering both, a microeconomic and a macroeconomic approach.

The investigation focused aspects such as: (i) Market Efficiency of the BM\&F Sugar Futures for Brazilian hedgers, by providing unbiased forecasters of future spot prices; (ii) the relative effectiveness in hedging for price risk, considering domestic and international sugar futures markets such as the Cocoa, Sugar and Coffee Exchange CSCE (New York) and the London International Financial and Futures Exchange LIFFE; (iii) cross hedge influence of international sugar market upon BM\&F; and (iv) interest rate effect upon the volume of sugar futures contracts negotiated at BM\&F (macroeconomic approach).

The results allowed for the conclusion that the use of the Sugar Futures Market at BM\&F may have been restricted, but not due to the influence of the factors evaluated in this analysis. 


\section{INTRODUÇĀO}

\subsection{Considerações Gerais}

Os mercados futuros e de opções têm experimentado, em anos recentes, um processo intenso de utilização de seus instrumentos de gerenciamento de riscos. Lozardo (1998) afirma que, em um estudo realizado pelo Bank for International Settlements (BIS), registrou-se que o volume de contratos de derivativos em aberto, ao final de março de 1995, somavam em valores monetários, US\$ 47 trilhões.

Impulsionada por processos de desregulamentação de seus mercados, a participação dos paises em desenvolvimento nesses segmentos tem sido cada vez maior. No caso da commodity açúcar, por exemplo, Larson et alli (1998) ressaltam que, de acordo com algumas estimativas, cerca de $50 \%$ do crescimento dos negócios com os contratos dessa commodity, nos últimos anos, nas bolsas de Londres e Nova Iorque, são atribuídos ao maior uso desses mecanismos de administração de riscos de preço pelos países produtores. Em geral, os países produtores dessa commodity são nações em desenvolvimento onde o governo tem passado a considerar o mercado de açúcar como importante fonte de divisas.

$\mathrm{Na}$ economia brasileira, a condução política do setor sucroalcooleiro vem seguindo tendências mundiais de desregulamentação e de aumento da participação do setor privado na gerência dos riscos associados à atividade. À medida em que avança a desregulamentação, a necessidade de operar sob um novo contexto tem motivado o setor privado a adequar suas tomadas de decisões, a fim de assegurar uma atuação eficiente 
sob condições mais competitivas.

O setor sucroalcooleiro brasileiro tem encontrado, no entanto, dificuldades para atuar nesse processo de reorganização e adaptação dos mercados de seus produtos. Temse evidenciado a inexistência de mecanismos domésticos formais para a administração de riscos associados a mudanças não esperadas de preços. Contudo, o lançamento do Contrato Futuro Cambial do Açúcar Cristal pela Bolsa de Mercadorias e Futuros (BM\&F) apresenta-se como uma iniciativa importante tomada no sentido de suprir essa deficiência de instrumentos privados para o gerenciamento de risco.

O objetivo principal do lançamento desse contrato foi o de auxiliar produtores, refinadoras, distribuidoras, assim como exportadores de açúcar, a operar em mercados desprovidos de políticas governamentais regulamentadoras. Este processo de desregulamentação teve como consequência direta um incremento da volatilidade dos preços, e, por conseguinte, uma maior dificuldade para prever as receitas auferidas pelo setor.

Contudo, o bom desempenho desse serviço depende, como em qualquer outra atividade, tanto de fatores de mercado quanto de aspectos conjunturais. A economia brasileira esteve exposta, na década de 1990, a diversos choques econômicos, que se devem não só a ajustes internos, provocados por políticas de estabilização monetária e equilíbrio fiscal, como também a ajustes promovidos para minimizar os efeitos dos distúrbios financeiros internacionais sobre a economia doméstica.

A instabilidade econômica tem provocado elevados custos de ajustamentos nos vários setores da economia. A forma como as políticas macroeconômicas têm sido conduzidas, pode provocar distorções em análises de viabilidade de projetos de investimentos, sejam esses produtivos ou financeiros. No que tange aos investimentos nos setores produtivos, uma elevação do nível de taxa de juros pode tornar tais projetos inviáveis do ponto de vista da rentabilidade. Uma elevação do custo de oportunidade pode também provocar um aumento nos custos de carregamento, inviabilizando a atuação dos armazenadores de commodities, como o açúcar. Portanto, mudanças nas variáveis macroeconômicas decorrentes desses ajustes, geram distorções que podem 
influenciar o desempenho do Contrato Futuro Cambial do Açúcar Cristal da BM\&F.

Por outro lado, a existência de instrumentos alternativos de gerenciamento de risco pode também influenciar o desempenho desse contrato considerando-se, como fazem Tsetsekos e Varangis (1997), as transações com derivativos nos diferentes países como serviços competitivos globais. Contudo, além da função básica de proporcionar a transferência de risco entre os investidores, os mercados futuros também funcionam como importantes indicadores das expectativas sobre o comportamento dos preços de um ativo. A capacidade dos mercados futuros em proporcionar uma boa previsão de preços futuros é condição necessária para a efetiva redução de riscos nesses mercados. Essa capacidade pode ser definida como eficiência dos mercados futuros, sendo portanto, o objetivo central desse trabalho, verificar de que forma o Contrato Futuro Cambial do Açúcar Cristal da BM\&F tem desempenhado suas funções de previsão de preço e redução de risco frente a mercados futuros internacionais do açúcar.

\subsection{O Enfoque da Pesquisa}

Os operadores do mercado de derivativos podem ser categorizados segundo Hull (1998) como hedgers, especuladores ou arbitradores. Para Lozardo (1998) hedger é aquele que produz ou possui fisicamente o produto, de forma que seu único objetivo é proteger-se do risco de mercado no preço de sua commodity. Já os especuladores têm como objetivo lucrar com as oscilações de preços no mercado futuro, assumindo portanto riscos de mercado. É importante frisar que um especulador também pode assumir uma posição vendida em mercados futuros, fato esse que dependerá de sua estratégia. Por sua vez, os arbitradores, conforme ressalta Hull (1998), podem realizar um lucro sem risco realizando transações simultâneas em dois ou mais mercados.

Nessa pesquisa adotar-se-á a consideração de Working (1953 e 1954), citado por Black (1986), de que o volume negociado de um contrato futuro é determinado pelo montante de posições vendidas assumidas pelos hedgers. Dessa forma, as hipóteses 
feitas referem-se ao processo de tomada de decisão do hedger. Com isso, pretende-se inferir sobre a forma pela qual as variáveis consideradas nesse trabalho têm influenciado o volume de negociação do contrato do açúcar no Brasil.

Portanto, nesse tópico busca-se explanar as investigações que serão conduzidas nesse trabalho a respeito da performance do Contrato Futuro Cambial do Açúcar Cristal da BM\&F. Em primeiro lugar, trata-se do grau com que esse mercado futuro vem sendo eficiente para o hedger brasileiro em fornecer previsões não viesadas dos preços spot, assim como proteção contra o risco de variação não esperada de preço, frente aos Mercados Futuros Internacionais do açúcar mais importantes. Nessa mesma linha, a possível influência dos cross hedges sobre o montante transacionado do contrato brasileiro é averiguada, ressaltando a importância desses serviços substitutos para a proteção do risco de preço do ponto de vista de um hedger brasileiro. Em segundo lugar, apresenta-se uma verificação de possíveis impactos dos aspectos conjunturais, mais precisamente, a forma pela qual a variação da taxa de juros pode influenciar o volume de negócios do Contrato Futuro Cambial do Açúcar da BM\&F.

\subsubsection{Cross Hedge, Eficiência de Mercado e Eficiência de Hedge}

Dentre algumas hipóteses que podem ser testadas quanto aos fatores determinantes das oscilações do volume negociado do Contrato Futuro Cambial do Açúcar da BM\&F, tem-se a existência de contratos substitutos. $O$ uso limitado desse instrumento pode ser decorrência da existência de contratos alternativos, que, talvez, apresentem maior eficiência e menores custos de liquidez. Os contratos de açúcar transacionados na Coffee, Sugar and Cocoa Exchange (CSCE), em Nova Iorque, e na London International Financial Futures \& Options Exchange (LIFFE), em Londres, apresentam grandes volumes de negociação, podendo ser considerados potenciais substitutos do Contrato Futuro Cambial do Açúcar Cristal da BM\&F.

Grande parte dos estudos voltados à análise da evolução dos mercados futuros no 
Brasil, assim como em outros paises em desenvolvimento, têm utilizado de preceitos baseados na teoria microeconômica para a condução das análises, tal como Black (1986), dentre outros. Thompson et alli (1996), por outro lado, investigam o fracasso de um contrato de açúcar extraído do milho', lançado em abril de 1987, fazendo uma descrição das inter-relações e do comportamento dos participantes desse mercado. Esses autores conduziram a pesquisa fazendo entrevistas, via telefone, com as empresas, produtoras e consumidoras, envolvidas nesse segmento. Foi utilizada ainda, nesse trabalho, uma análise de correlação entre os preços spot e futuros cujos resultados indicaram que esse contrato não era utilizado como mecanismo de hedging, ou para a descoberta de preço. As principais razões apresentadas para o fracasso do contrato, de acordo com as entrevistas feitas por Thompson et alli (1996), foi a utilização preferencial de contratos a termo e transações no mercado fisico, pelos participantes, e a falta de liquidez desse contrato futuro. Os custos de carregamento também são citados como um empecilho para a utilização desse contrato futuro porque não eram cobertos pelos retornos auferidos, caso houvesse estocagem do produto e venda em período futuro.

Uma das funções do Mercado Futuro é fornecer proteção ao hedger face a uma variação inesperada do preço de determinada commodity. Nesse sentido, a eficiência do hedging diz respeito à capacidade de um Contrato Futuro em fornecer proteção contra variações inesperadas do preço da mercadoria, objeto do contrato, quando comparado a uma situação em que não se realiza o hedge. Se um determinado contrato não está sendo eficiente segundo esse conceito, sua existência pode tornar-se inviável devido a uma utilização restrita o que acaba por acarretar um elevado custo de liquidez e comprometimento do seu sucesso.

Sendo consensual que o volume de negociação é um indicativo incontestável de sucesso de um determinado contrato, Black (1986) afirma que, se um contrato futuro já

\footnotetext{
${ }^{1}$ De acordo com Thompson et alli (1996) o High Fructose Com Syrup-55 (HFCS-55) foi desenvolvido no final da década de 70 como uma alternativa líquida de adoçante para substituir o açucar convencional. $O$ número 55 refere-se ao teor de frutose $(55 \%)$ contido nesse produto.
} 
existe para um substituto próximo (cross hedge), a redução do risco residual ${ }^{2}$ derivado de um novo contrato de hedge é pequena, o que pode tornar inviável a operação de hedge nesse novo mercado. A chance de sucesso do contrato novo é pequena quando um cross hedge disponivel já fornece o serviço de proteção aos hedgers da commodity. Por outro lado, se existem cross hedges (contratos substitutos) que deixam o hedger com um grande risco residual, então pode existir o nicho de mercado para o novo contrato.

Contudo, Black (1986) afirma que o co-movimento de preços spot e futuro de commodities relacionadas, provavelmente é menos confiável e consistente do que as relações de preços spot e futuro para o mesmo produto. Desta forma, o risco de base ${ }^{3}$ é maior para o cross hedge do que para o hedge direto, ou "own hedge" (onde own hedge é definido como posição assumida no mercado futuro no qual o objeto do contrato é a mesma commodity da posição do mercado físico). A autora utiliza para a comparação da eficiência relativa de hedge do contrato novo frente ao cross hedge, a variável risco residual relativo, que é uma medida de quanto uma nova modalidade de contrato reduz o risco de mudança de preço quando o "novo" contrato é utilizado ao invés de se usar o cross hedge.

Varangis e Larson (1996) também afirmam que o sucesso de um contrato é condicionado à existência ou não de um cross hedge eficiente ${ }^{4}$, além do tamanho do mercado fisico e variabilidade do preço da commodity em questão. Porém, mesmo com certos entraves, estes autores defendem o estabelecimento de um contrato futuro doméstico. Para eles, dois importantes benefícios que emergem da implantação de um mercado futuro, são:

(i) a descoberta de preço; e

\footnotetext{
${ }^{2}$ Black (1986) define risco residual como o risco de permanecer em uma posição de hedge, quando comparado com o hedge perfeito. Sendo que no hedge perfeito todos o riscos são eliminados.

${ }^{3}$ Lozardo (1998) refere-se ao risco de base como o risco associado a um diferencial entre o preço à vista do ativo e do contrato futuro devido à incerteza do valor da base no tempo. Porém, muitas vezes, reportase ao risco de base como sendo o risco da não convergência do preço à vista para o preço futuro no vencimento do contrato.

${ }^{4}$ Black (1986) define cross hedge eficiente como um contrato que apresenta baixo custo de liquidez e risco residual pequeno
} 
(ii) a redução do risco de base.

Os mercados futuros domésticos podem envolver menor risco de base porque os contratos futuros representam a commodity em um local mais próximo do mercado físico.

Todavia, Varangis e Larson (1996) enfatizam que uma das pré-condições básicas para o estabelecimento de um mercado futuro doméstico é a existência de um mercado físico com preços transparentes. Para esses autores, isso implica que o mercado spot não pode ser monopolizado por firmas privadas e nem por entidades públicas. Porém, mesmo que esta condição seja básica para que possa haver transações com mercados futuros, não se pode garantir, segundo Varangis e Larson, que um contrato futuro terá sucesso. As principais condições para que um contrato futuro tenha sucesso, de acordo com esses autores podem ser resumidas da seguinte forma:

(i) os preços da commodity no mercado físico e no mercado futuro devem ser altamente correlacionados; e

(ii) a commodity, objeto do contrato, deve ser padronizada em termos de tamanho, classificação, qualidade, local de entrega, e mês de vencimento, de forma que se garanta a homogeneidade dos contratos.

Contudo, a forma com que o Mercado Futuro do Açúcar da BM\&F vem desempenhando sua função de descoberta de preço pode não estar sendo tão eficiente quanto as alternativas que o hedger brasileiro pode encontrar nos mercados internacionais, o que também pode restringir a utilização mais ampla desse instrumento de proteção de risco de preço. Portanto, isso requer, uma averiguação mais aprofundada das características do mercado futuro do açúcar para o hedger doméstico, com relação a:

(i) sua eficiência em fornecer previsões não viesadas dos preços spot - Eficiência de Mercado -;

(ii) sua eficiência em fornecer proteção contra o risco de variação não esperada de preço - Eficiência do hedging -;

(iii) o grau com que os cross hedges se apresentam eficientes em desempenhar as 
atribuições descritas nos itens (i) e (ii), e também em reduzir o risco residual.

\subsubsection{A Taxa de Juros e a Own Rate}

Desde a década de 1930, vários estudos têm buscado captar relações entre variáveis macroeconômicas e preços de commodities. Moalla-Fettini (1990) afirma que a Teoria da Estocagem e a Abordagem da Arbitragem incorporam as taxas de juros nominais nos spreads $s^{5}$ dos preços das commodities, muito embora exista uma linha de pesquisa mais recente que tem sugerido uma associação entre a taxa própria da commodity - taxa implícita de retorno - e a taxa de juros real.

Para Moalla-Fettini (1990), as relações existentes entre os preços das commodities e as taxas de juros merecem atenção por várias razões. Uma delas é que estas relações servem como um componente chave na determinação do impacto de políticas macroeconômicas (monetárias) em setores de commodities primárias, como é o caso da agricultura. Em segundo lugar, estas relações são importantes para detectar se há ou não neutralidade da política monetária. Como os preços das commodities são, por natureza, relativamente flexíveis, no caso de se ter uma não-neutralidade monetária, mudanças nas taxas de juros reais provocarão efeitos sobre os preços reais desses produtos. Assim sendo, estudos quanto à importância da taxa de juros reais na determinação dos preços desses bens podem fornecer informações relevantes quanto à não-neutralidade dos impactos monetários. Terceiro, e a um nível mais institucional, como ressalta o referido autor, estas relações podem refletir as ligações existentes entre os mercados financeiros e os mercados de commodities.

A taxa de juros é um fator fundamental na tomada de decisão dos agentes econômicos. Da mesma forma que uma elevação substancial da taxa de juros pode provocar a inviabilidade de vários projetos de investimento, supõe-se que ela também

\footnotetext{
${ }^{5}$ Moalla-Fettini (1990) algumas vezes utiliza o termo spread para indicar a base (diferença entre os preços spot e futuro). Já para Barnhart et alli (1996) o spread é a diferença entre os preços de diferentes contratos futuros. No presente estudo, referir-se-á ao spread como fazem Barnhart et alli (1996).
} 
tenha influência sobre os mercados futuros de commodities.

Nos últimos anos, situações de choques de taxa de juros não antecipados pelos agentes econômicos ocorreram na economia brasileira. Mais recentemente, importantes fatores geradores desses choques têm sido as crises financeiras internacionais e a mudança interna de regime cambial. A Figura 1 ilustra a relação entre as oscilações das taxas de juros, mudança do regime cambial, e as crises financeiras internacionais.

$\mathrm{O}$ aumento do volume de negociação de commodities sugere a necessidade da reinterpretação da taxa de retorno desses produtos. As taxas de retorno das commodities deveriam refletir seu custo de oportunidade, de forma que a taxa de retorno, ou taxa própria (own rate), deveria ser igual ao retorno spot (mudança percentual no preço spot ou à vista) mais o custo de oportunidade do dinheiro (taxa de juros), segundo Satyanarayan e Varangis (1994).

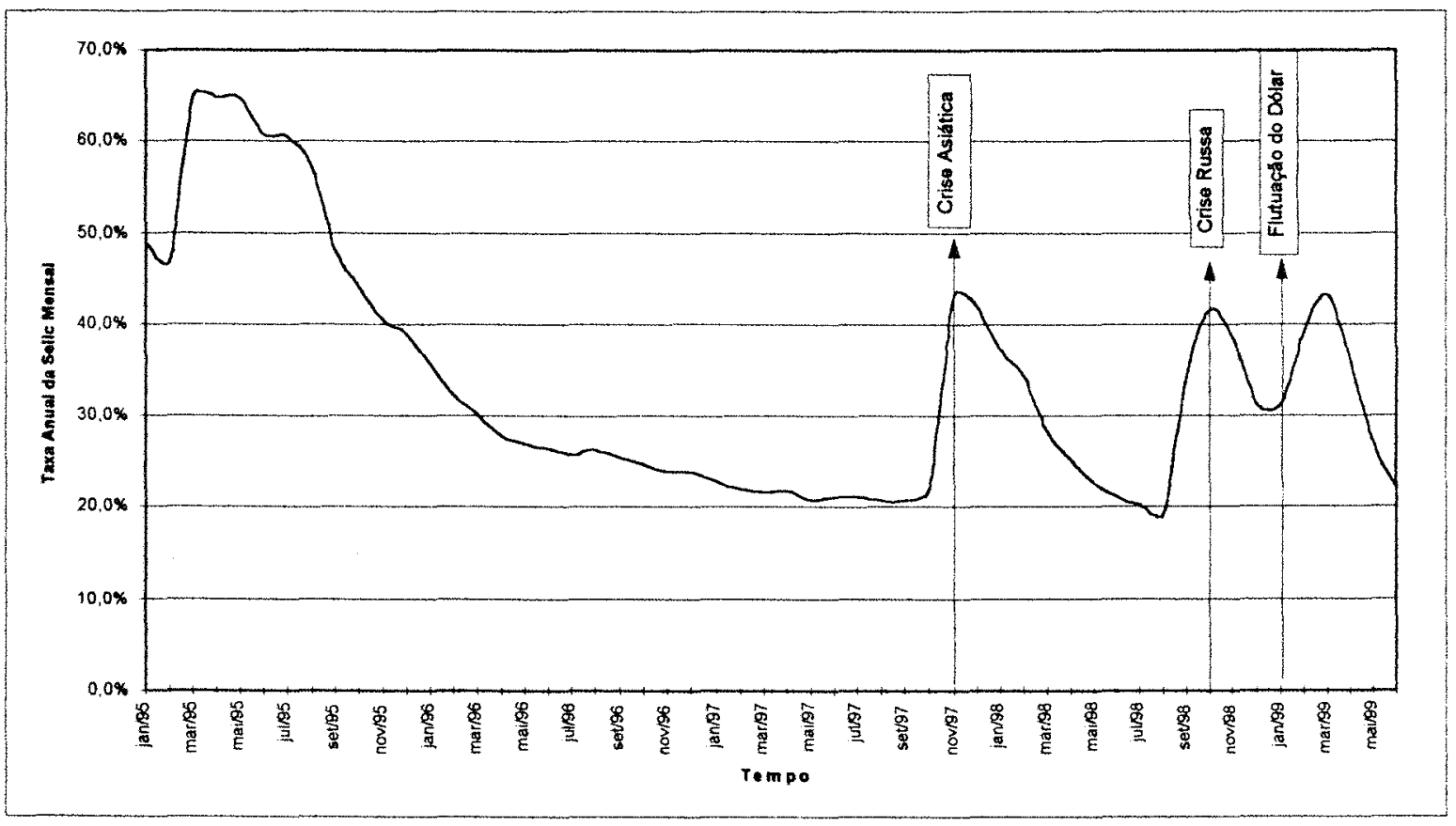

Figura 1. Taxas de Juros Nominais Anualizadas da Selic Mensal- Jan/95 - Jun/99.

Fonte: Boletim do Banco Central do Brasil, vários volumes. 
Para Gilbert (1985), transações com mercados futuros envolvem um custo financeiro relativamente importante para os hedgers. Esse custo deve-se não somente ao depósito da margem de garantia exigida pela bolsa na qual se opera, mas também pela própria manutenção desta margem. Ou seja, o hedger tem que desembolsar montantes financeiros com determinada periodicidade, caso tenha assumido, por exemplo, uma posição vendida em mercados futuros e tenha ocorrido um aumento do preço da commodity, objeto do contrato.

Dessa forma, Gilbert (1985) afirma que os custos (taxa de juros) e as dificuldades para captação financeira junto ao mercado de crédito, podem ser fatores determinantes da pequena utilização de operações de hedge em mercados futuros para assegurar receitas para os produtores de commodities primárias.

Bond (1984) chama a atenção para uma situação na qual ocorre um choque de juros tal que a elevação da taxa torne o mercado futuro de commodities menos atrativo frente às aplicações em ativos financeiros. Isso ocorre, essencialmente, por causa do aumento dos custos de estocagem.

Nessa situação, para os hedgers, o impacto se dá à medida em que se tem a percepção de que o aumento dos custos de carregamento foi em uma dimensão que não pode ser compensada pelo retorno propiciado pela estocagem. Portanto, ao se optar pela alternativa de vender os estoques, caso haja a estratégia de mantê-los hedgeados, estarse-á provocando uma diminuição no volume de posições assumidas em mercados futuros.

Assim sendo, para que o equilibrio inicial seja restabelecido, torna-se necessário que o retorno sobre os estoques hedgeados aumentem a ponto de reconstituir a atratividade da negociação em mercados futuros frente às aplicações em ativos financeiros. (Bond, 1984)

No Brasil, desde que o Contrato Futuro Cambial do Açúcar Cristal pela Bolsa de Mercadorias e Futuros - BM\&F foi lançado, em setembro de 1995, este vem apresentando bruscas oscilações de seu volume de negócios, como pode ser visualizado 
na Figura 2.

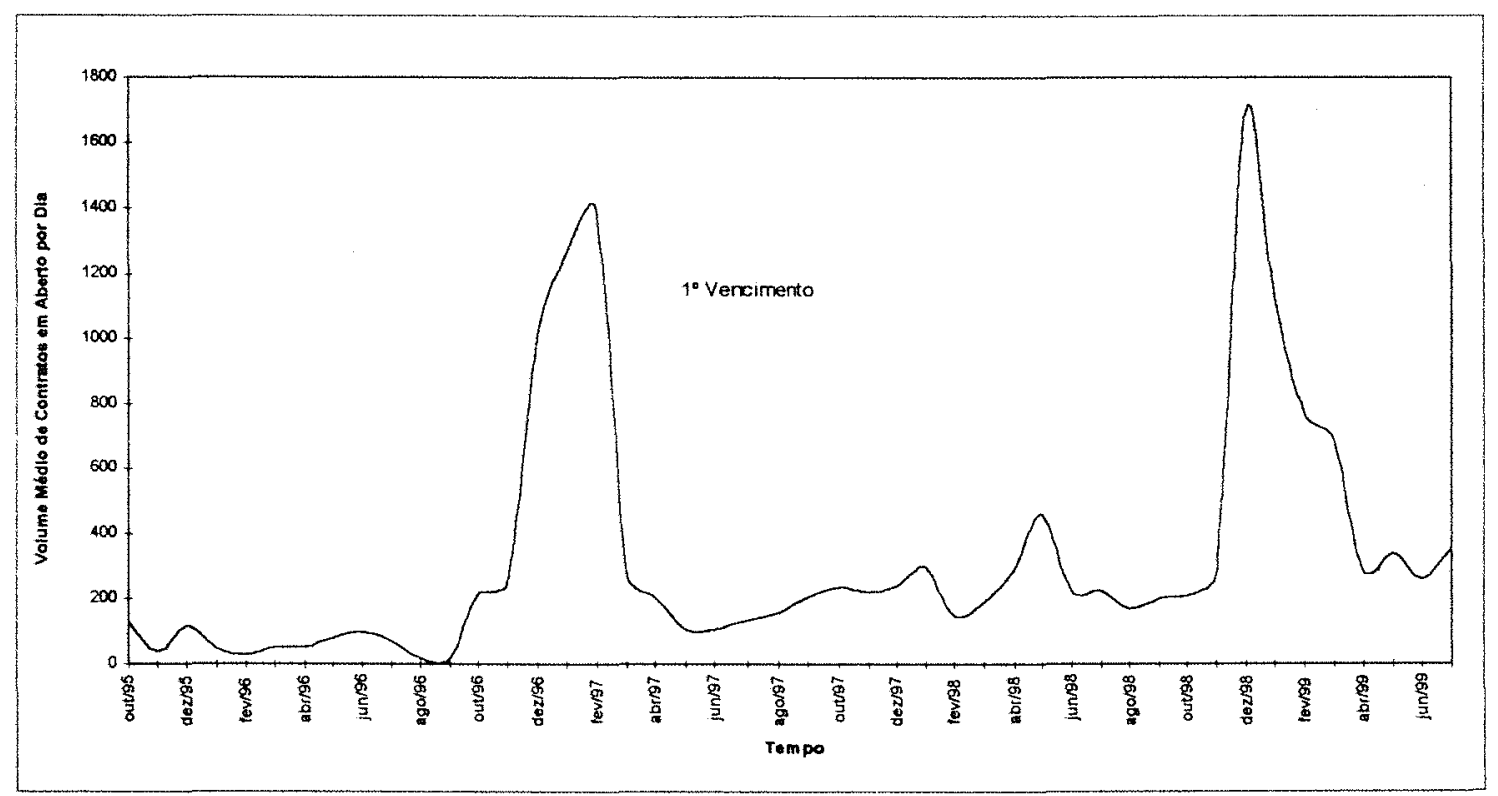

Figura 2. Volume de Negócios do Contrato Futuro Cambial do Açúcar Cristal na BM\&F Fonte: Site da BM\&F, na Internet.

Nesse âmbito, o presente trabalho pretende averiguar se existe relação entre a taxa de juros de mercado, a taxa própria do açúcar e o volume de contratos negociados na BM\&F. A pressuposição é de quando a taxa de juros é relativamente mais alta do que a taxa pela qual o mercado futuro remunera o açúcar, a viabilidade econômica de manutenção dos estoques fica comprometida, e, portanto, reduz-se as posições em aberto nos mercados futuros devido ao aumento nos custos de carregamento. Portanto, isso afeta o volume de posições vendidas assumidas pelos hedgers que estão mantendo a commodity em estoques. Vale ressaltar que, esse caso, aplica-se à análise da parcela de posições em mercados futuros que tenham como objetivo proteger o hedger que se mantém na espera de preços melhores no mercado à vista para disponibilizarem seus 
estoques.

O presente trabalho pretende contribuir, dessa forma, para o desenvolvimento de um senso crítico direcionado à análise da evolução de mercados futuros em países em desenvolvimento, empregando relações derivadas de preceitos microeconômicos (análises de eficiência), além de investigar uma possível relação do volume de contratos negociados com variáveis macroeconômicas, mais precisamente, a taxa de juros.

\subsection{Objetivos}

Este trabalho tem como objetivo geral investigar como alguns possíveis entraves à utilização do Contrato Futuro Cambial do Açúcar, negociado na Bolsa de Mercadorias e Futuros (BM\&F), têm influenciado seu desempenho. A análise enfoca apenas o comportamento do hedger (aquele que busca administrar o risco de preços) e considera o comportamento dos especuladores (participantes do mercado que se dispõem a tomar o risco de preços) como sendo dependentes das ações dos hedgers (Working, 1953). O período de abrangência da pesquisa vai desde o lançamento do Contrato Futuro dessa commodity, pela BM\&F, em setembro de 1995, até julho de 2000. A investigação busca identificar a existência de "pontos de estrangulamento", que possam estar restringindo uma utilização mais ampla desse instrumento, considerando aspectos de natureza micro e macroeconômicas. Mais especificamente pretende-se:

i) avaliar o desempenho apresentado pelo Contrato Futuro do Açúcar da BM\&F, com base na verificação de resultados relativos a testes de eficiência de mercados futuros;

ii) avaliar e comparar a eficiência do hedging, para hedgers nacionais do mercado de açúcar, os quais podem utilizar tanto o Contrato Futuro Cambial do Açúcar da BM\&F quanto os contratos futuros da CSCE e da LIFFE;

iii) avaliar a variável risco residual relativo para a utilização do contrato futuro da BM\&F frente a possiveis cross hedges considerados nessa pesquisa, contratos futuros do açúcar da CSCE e da LIFFE; 
iv) proceder a uma análise de correlação do volume de negociação do Contrato Futuro Cambial do Açúcar com o diferencial entre a taxa de juros e a taxa de remuneração da commodity no mercado futuro. 


\section{O SETOR SUCROALCOOLEIRO NO BRASIL}

Este capítulo tem como objetivo principal fazer algumas considerações sobre o processo de desenvolvimento do setor sucroalcooleiro e seu importante papel na evolução da economia brasileira. Para tanto, é dividido em três etapas principais: crescimento e crises, intervenção e desregulamentação.

\subsection{Crescimento e Principais Crises do Setor Açucareiro Brasileiro}

A indústria açucareira desempenhou um papel fundamental na formação econômica brasileira. Baer (1996) afirma que o primeiro produto de exportação importante do Brasil foi o açúcar. A rápida expansão do cultivo, que se iniciou em aproximadamente 1520 , e o acelerado crescimento das exportações dessa commodity, logo transformou a economia açucareira na primeira de uma série de ciclos de exportação primária, que iriam dominar o crescimento econômico do Brasil até o século $\mathrm{XX}$.

De acordo com Pina (1972), este período inicial tem sua marca na produção desordenada e no mercado fácil, época da descoberta do açúcar pela Europa. O número de engenhos aumentava abruptamente e no final do século XIV já somavam 115. De forma mais pontual, Simon (1997) descreve a evolução industrial do açúcar no Brasil, no período $1570-1700$, na forma apresentada na Tabela 1 .

Esta fase é marcada também pela carência de medidas governamentais que 
visassem amenizar as crises que o setor passava. Por outro lado, conforme ressalta Baer (1996), no início do século XVII o Brasil havia se tornado o principal fornecedor de açúcar do mundo, de forma que as exportações brasileiras de açúcar ganharam significativa evidência no continente europeu. Contudo, Pina (1972) afirma que as safras vantajosas estavam totalmente entregues às conveniências dos mercados europeus.

Tabela 1. Evolução Industrial do Açúcar no Brasil - Número de Engenhos.

\begin{tabular}{ccccc}
\hline Ano & Região Sul & Região Sudeste & Região Nordeste & Total \\
\hline 1570 & 5 & 31 & 24 & $\mathbf{6 0}$ \\
1583 & 13 & 52 & 66 & $\mathbf{1 3 1}$ \\
1610 & 40 & 50 & 140 & $\mathbf{2 3 0}$ \\
1629 & 70 & 84 & 192 & $\mathbf{3 4 6}$ \\
1645 & - & - & 77 & $\mathbf{3 0 0}$ \\
1700 & 136 & 146 & 246 & $\mathbf{5 2 8}$ \\
\hline
\end{tabular}

Fonte: Bennassar, Bartolomé, "La América Española y la América Portuguesa (siglos XVI a XVIII)", Editorial Sarpe, Madrid, 1985, pág. 157, in Simon (1997).

Sentindo os efeitos do regime competitivo, o açúcar esbarrou em meados do século XIX com a fase industrial. O governo então faz a primeira tentativa de intervenção na indústria açucareira oferecendo concessões para a instalação de engenhos centrais, dotados de maquinaria e que se formariam com a aglutinação das velhas fábricas condenadas ao desaparecimento. No entanto, conforme enfatiza Pina (1972), o propósito de modernizar a indústria não obteve o sucesso que era de se esperar, sendo bastante reduzido o número de estabelecimentos que surgiram em decorrência de tal proposta.

Uma das causas dessa intenção governamental não ter obtido o sucesso almejado foi que ela tinha que enfrentar os padrões já estabelecidos da estrutura social vigente, onde o senhor de engenho teria que abdicar de sua posição de produtor, de comando em seus domínios. 
Porém, foi no início do século XX que a indústria açucareira viveu períodos de bastante volatilidade da demanda pelo seu produto. Em alguns anos os preços chegaram a cair $50 \%$ e os números referentes à exportação de açúcar ilustram a crise do período como pode ser visualizado na Tabela 2.

Tabela 2. Volume de Açúcar Exportado, 1901-1923.

\begin{tabular}{lc}
\hline Ano & Sacas de $50 \mathrm{Kg}$ \\
\hline 1901 & 3.119 .435 \\
1904 & 131.024 \\
1906 & 1.415 .805 \\
1913 & 88.523 \\
1917 & 2.302 .649 \\
1918 & 1.927 .225 \\
1920 & 1.819 .014 \\
1923 & 2.552 .910 \\
\hline
\end{tabular}

Fonte: Pina, Hélio. A Agro-indústria Açucareira e sua Legislação. Apec Editora S/A. São Paulo. 1972. pág. 17.

De forma explícita, Pina (1972) afirma que foi o período da $1^{\mathrm{a}}$ Guerra Mundial (1914/1918) que ofereceu a última grande ilusão à livre competição. Foi após o início da Grande Guerra que o açúcar nacional voltou a figurar no mercado internacional de forma mais ou menos sólida. Isso porque a devastação produzida pela guerra suspendeu, naturalmente, a produção do açúcar de beterraba praticado naquela época na Europa. Contudo, a questão era ser esse apenas um fato transitório e que a recuperação do cultivo da beterraba na Europa significava o fim do despreocupado contentamento do produtor nacional.

Com as exportações caindo bruscamente, exatamente no ano da grande crise mundial de 1929, a produção total de açúcar atingiu, segundo o autor citado acima, a maior cifra registrada até então e os preços sofreram queda de mais de $60 \%$. 
Como a safra de 1930/31 estava ainda muito elevada e o preço oscilava em patamares bastante reduzidos, isto, associado a um modesto volume de exportação fez com que o governo que até o momento procurava manter-se distante dos problemas do setor, se deparasse em 1930 diante de um quadro que nada mais era do que um espelho da crise de 1929. Assim sendo parece que a situação não oferecia opções e nem era possível ficar indiferente ao problema.

\subsection{Intervenção Governamental no Setor Açucareiro}

A situação da indústria se agravava cada vez mais em decorrência das políticas adotadas pelos grandes países consumidores de açúcar da Europa e pelos Estados Unidos. Prado Jr. (1971) afirma que a participação do Brasil no comércio internacional declinou não apenas em termos absolutos, mas também em termos relativos. Essa situação deveu-se às políticas de proteção tarifária e outras concedidas à produção das respectivas colônias ou zonas de influência dos países de grande consumo.

Essa fase foi marcada também pelo início de um periodo o qual o Estado passou a traçar normas disciplinadoras para o setor. Pina (1972) afirma que a primeira medida foi um decreto de 15.09.1931 que criou normas preliminares à intervenção com vistas à garantia do preço do açúcar. Neste mesmo ano, em 7 de dezembro, criou-se através de decreto, a Comissão de Defesa da Produção do Açúcar, a ela competindo tomar as providências iniciais de controle da produção e da exportação, sempre com o objetivo de manter o equilíbrio de mercado.

Dentre essas providências iniciais, destinadas ao setor, os incentivos dados à produção alcooleira figurava como substrato mestre do sistema recém inaugurado. A indústria alcooleira iria funcionar junto às eventuais exportações de açúcar. O objetivo dessas medidas foi o de aproveitar as canas excedentes na fabricação do álcool. A idéia básica era que se a exportação estava condicionada a fatores externos, a mistura do álcool à gasolina daria imediato alento ao setor sucroalcooleiro, além de proporcionar 
economias de divisas.

Surgia assim de maneira mais formal o setor sucroalcooleiro, que tinha como órgão do Poder Público incumbido de elaborar projetos para o setor, o Instituto do Açúcar e Álcool (IAA). Jungmann (1971) afirma que a Comissão de Defesa do Açúcar foi transformada no IAA, através do decreto expedido em 25.07.1933, para que se pudesse de forma mais eficiente articular uma grande reforma na organização açucareira nacional e assim tentar recuperar um segmento de tão expressiva importância para a economia brasileira.

Contudo, estabelecer disciplina em um setor de tão grande importância e que até então atuava de acordo com as regras de livre mercado não era tarefa fácil. Ademais, a situação externa ficava cada vez mais caótica. Prado Jr. (1971) enfatiza que a participação brasileira no comércio internacional de açúcar tornou-se pouco expressiva com a quota de exportação do Brasil, fixada na Conferência Internacional de Londres em 1937, na casa dos modestos $1,6 \%$. Posto de outra forma, a situação do setor era ainda pior, principalmente com essa restrição que limitava a participação do açúcar brasileiro no comércio internacional em 1,6\%, o que fez com que o Brasil praticamente perdesse seu mercado externo.

Todavia, a imposição dessa quota foi abandonada ao estalar a II Guerra Mundial (1939-1945) e, mais uma vez, a expansão coincidiu com a possibilidade de exportação, a preços satisfatórios, dos excessos que estavam acumulados. Isso foi possível devido ao fato dos centros produtores da Europa e do Oriente, os quais haviam sofrido os efeitos da guerra, não se terem refeitos. O novo surto de exportação no pós-guerra pode ser visualizado na Tabela 3 .

Neste período houve uma necessidade de reconsideração por parte do IAA dos limites anteriormente impostos à produção. Pina (1972) afirma que se o IAA não cedesse à marcha ascendente do consumo, ou seja, se não exercesse as limitações impostas de forma mais maleável, o sentido de sua existência poderia tornar-se um contra-senso, uma vez que estaria impondo limites ao bom desempenho do setor, neste periodo. Contudo, este autor enfatiza que o fato do país haver partido das 300.000 sacas, 
exportadas em 1933, para 18 milhões, em 1969, consolida o princípio de que as normas disciplinadoras são essenciais para o afastamento das aventuras da oferta desordenada.

Tabela 3. Volume de Açúcar Exportado, 1930-1969.

\begin{tabular}{cr}
\hline Ano & Sacas de $50 \mathrm{Kg}$ \\
\hline $1930 / 31$ & 84.937 \\
$1940 / 41$ & 97.820 \\
$1948 / 49$ & 5.198 .332 \\
$1950 / 51$ & 15.821 \\
$1955 / 56$ & 9.683 .042 \\
$1960 / 61$ & 14.246 .241 \\
1969 & 18.044 .670
\end{tabular}

Fonte: Pina, Hélio. A Agro-indústria Açucareira e sua Legislação. Apec Editora S/A. São Paulo. 1972. pág. 41 .

Porém, o IAA que adquiriu força nas décadas de 1930, 1940 e 1950 com sua autonomia para regulamentar a economia açucareira, através das quotas de produção e fixação de preços, passou por uma restruturação em meados dos anos 1960. De acordo com Jungmann (1971), a partir de 1965 seguiu-se um progressivo esvaziamento do IAA pelo diferimento a outros órgãos da Administração Pública de atribuições que antes eram da sua competência administrativa. Dentre elas, pode-se citar as mais importantes:

i) a concessão de empréstimos para reequipamento e modernização do Parque Industrial foi transferida para o Banco Central;

ii) a concessão de financiamentos às usinas passou a depender do Conselho Monetário Nacional; e

iii) a Superintendência Nacional de Abastecimento (SUNAB) passou a intervir na política de fixação do preço do açúcar.

A década de 1970 foi também alvo de políticas intervencionistas do governo. 
Através do IAA, deu-se incentivo às fusões e incorporações de usinas por todo o país além do estabelecimento no início dos anos 1970 de uma nova cota de produção nacional. Conforme ressalta Moraes (1999) o país pôde reduzir o estoques acumulados e se tornar o primeiro produtor mundial de açúcar centrifugado de cana, sendo que ao mesmo tempo tornou-se o segundo exportador. A exportações brasileiras de açúcar cresceram $180 \%$ entre 1969 e 1973.

Em novembro de 1975 foi criado, pelo governo, o Programa Nacional do Álcool, com o objetivo diminuir a exposição do país às crises internacionais do petróleo que ocorreram nesta década. Dessa forma, a produção do açúcar ficava ameaçada pela produção do álcool, surgindo inclusive, a possibilidade de não se atender os compromisso externos de exportação de açúcar. Para se ter uma idéia das medidas adotadas pelo governo nesta fase, na safra 1977/78 o IAA permitiu a transformação de 15 milhões de sacos de açúcar em álcool direto.

Na década de 1980, a situação não foi diferente do cenário iniciado nos anos 1970. Com o consumo do álcool como combustível de veículos automotores em ascensão, a produção de açúcar passou para segundo plano. Moraes (1999) afirma que no início da década de $1970,96 \%$ do álcool era obtido de forma indireta, como um subproduto do açúcar, mas que a partir da criação do Programa Nacional do Álcool, começou a crescer a importância relativa do álcool no contexto da agro-indústria canavieira. A participação do álcool no setor atingiu tais proporções que na safra de 1985/86, mais de $60 \%$ da cana-de-açúcar foi usada para a produção desta forma alternativa de combustível.

Contudo, o setor sucroalcooleiro começou a passar por uma fase, em meados da década de 1980, que necessitava de uma avaliação. Pelo lado interno, os programas macroeconômicos de estabilização monetária tiveram como consequência imediata uma paralisação das linhas de crédito destinadas ao financiamento da ampliação da capacidade instalada. Esgotava-se o apoio que até então era dado a setor. Concomitantemente, pelo lado externo, o mercado de petróleo vivia uma situação que os preços internacionais começaram a declinar. 


\subsection{Desregulamentação do Setor Sucroalcooleiro}

O esgotamento do modelo de intervenção estatal, ocorrido no início dos anos 1990, foi decorrência, para Moraes (1999), de uma série de transformações pelas quais o pais passava, dentre elas:

(i) início do processo de abertura comercial aos mercados externos;

(ii) falência do Estado Brasileiro;

(iii) mudanças ocorridas no ambiente institucional do pais, que caminha em direção a consolidação do regime democrático.

Porém, o mais forte argumento que justificou a desregulamentação do setor tem base na Constituição Federal de 1988, a qual redefine o papel do Estado na economia brasileira. Essa Constituição reformulada estabelece que o planejamento estatal deve ter apenas um caráter indicativo, o que enfraquece a ação governamental.

Portanto, a partir da reforma administrativa ocorrida no início dos anos 1990, dentro do contexto de liberalização econômica, surge uma forma institucional para a política decisória do álcool e do açúcar, modelada ao novo cenário.

A autora citada anteriormente, afirma que os efeitos do processo de liberalização, sobre $a$ setor sucroalcooleiro, fazem-se sentir no seu ambiente institucional e organizacional. Dentre os efeitos mais imediatos, no ambiente organizacional, tem-se o abandono do sistema de fixação de preços dos insumos e produtos desta cadeia e das suas formas regulamentadas de comercialização. Ainda pode-se citar o fim da emissão pelo governo dos Planos de Safra e controle da produção.

A mudança no ambiente institucional começa com a extinção do Instituto do Açúcar e Álcool (IAA), em março de 1990, sendo que parte das atribuições deste Instituto foram transferidas aos órgãos e entidades da Administração Pública Federal.

Portanto, o setor passou atuar sobre formas competitivas de mercado. A produção 
de açúcar, conforme pode ser visualizada na Tabela 4, do país voltou a crescer, principalmente depois do esgotamento do Programa Nacional do Álcool.

Tabela 4. Evolução da Produção e Exportação de Açúcar no Brasil - 1988/89 a 1998/99.

\begin{tabular}{ccc}
\hline Safra & Produção(Ton.) & Exportação (Ton.) \\
$1988 / 89$ & 8.070 .212 & 1.546 .032 \\
$1989 / 90$ & 7.264 .180 & 1536.368 \\
$1990 / 91$ & 7.426 .310 & 1.405 .282 \\
$1991 / 92$ & 8.658 .361 & 1.704 .447 \\
$1992 / 93$ & 9.389 .303 & 2.144 .644 \\
$1993 / 94$ & 9.419 .395 & 2.554 .989 \\
$1994 / 95$ & 11.854 .337 & 4.167 .381 \\
$1995 / 96$ & 12.703 .009 & 4.516 .847 \\
$1996 / 97$ & 13.648 .527 & 4.803 .474 \\
$1997 / 98$ & 14.853 .662 & 6.123 .153 \\
$1998 / 99$ & 17.824 .381 & 6.423 .100 \\
\hline
\end{tabular}

Fonte: Queiroz Neto, (1999), in Moraes (1999), p.8-9.

O país voltou ainda a figurar no mercado internacional como o maior exportador de açúcar do mundo, e as exportações brasileiras cresceram nos últimos dez anos em mais de $120 \%$ como pode ser visto na Tabela 4 .

Portanto, é nesse contexto de incertezas, em um ambiente de livre mercado, que atua o agente econômico desse setor, sem o apoio em última instância do Estado, que garantia preços mínimos, limite de produção, financiamentos a taxas subsidiadas, aquisição de excedentes, dentre outras regalias, como ocorria em tempos idos. 


\subsection{O Contrato Futuro Cambial do Açúcar da BM\&F}

Fruto do processo de desregulamentação que o setor sucroalcooleiro tem passado, o Contrato Futuro Cambial do Açúcar começou a ser negociado em setembro de 1995 na BM\&F. De acordo com Schouchana (1997) foi a primeira vez que se negociou um contrato futuro de açúcar no Brasil, já que até 1990 o preço dessa mercadoria era tabelado pelo governo, através do IAA.

A criação desse instrumento de administração de risco de preço deveu-se a uma demanda por esse serviço, por parte do setor sucroalcooleiro, junto à BM\&F. Com o processo de desregulamentação esse setor tem percebido a necessidade de se adequar à nova realidade do mercado, que está mais competitivo. 


\section{MERCADOS FUTUROS DE COMMODITIES AGRÍCOLAS}

\subsection{Importância Econômica dos Mercados Futuros de Commodities Agrícolas}

As commodities agrícolas são, não só fonte de alimento e matéria prima, mas também fonte de renda para diversas famílias e comunidades. Para vários países propiciam ainda receitas de exportação e renda para os respectivos governos. Dada a importância dessa classe de produtos, os setores público e privado têm mostrado um crescente esforço para administrar os riscos de preços das commodities. Isto se deve à extrema dependência às receitas derivadas dessas commodities. Em algumas economias, esta dependência, associada à volatilidade de preços, pode tornar-se um empecilho importante para o desenvolvimento econômico.

Face à sua relevância, tem-se observado diversas tentativas de desenvolvimento de programas institucionais nacionais e internacionais de estabilização de preços das commodities. Durante o século XX, esses programas tiveram como objetivo tratar da ruptura e do efeito negativo resultante da instabilidade de preços dessa classe de bens, além de diversas consequências da volatilidade dos mercados de commodities.

A crescente preocupação de analistas com a volatilidade de preços desses produtos deve-se não só à dimensão de mercados de países como o Brasil, Argentina, China, México, como também pelo intenso e contínuo processo de desregulamentação desses mercados. As privatizações, reformas comerciais e estruturais nos mercados de capitais, associadas ao fracasso dos programas de sustentação de preços, têm resultado em redução da intervenção governamental no mercado de commodities e aumento na 
participação do setor privado. Desta forma, o aumento da participação do setor privado tem contribuido para a utilização de instrumentos de administração de riscos de preços das commodities.

O desenvolvimento do mercado financeiro de vários paises emergentes tem sido expressivo em muitos dos seus segmentos. O processo inflacionário, que prevaleceu nas décadas de 1980 e 1990, tornou o sistema financeiro desses países bastante complexo. Concomitantemente, a incapacidade dessas nações de equilibrar o orçamento público, provocou falhas de políticas governamentais, aumentando o risco para os agentes econômicos. $\mathrm{O}$ fracasso dos acordos internacionais de commodities (AIC's), frente às novas regras de liberalização do comércio internacional, assim como o esgotamento das potencialidades das políticas de sustentação de preços conduzidas pelos paises em desenvolvimento, provocaram mudanças bruscas na forma de alocação e administração dos riscos de preços de commodities agricolas.

Essas transformações provocaram uma diminuição da intervenção governamental e um forte estímulo à gestão da comercialização pelo setor privado. Isso tem levado a uma melhor adequação do comportamento dos agentes econômicos às novas regras de mercado, à medida em que vários setores da economia tornam-se mais concorrenciais. Em um ambiente de incertezas têm-se desenvolvido os mercados futuros de commodities, cujas principais funções consistem em dar transparência a preços e proporcionar a possibilidade de transferência de riscos entre os agentes de mercado.

O mercado de commodities é relativamente volátil. Os preços desses produtos mudam diariamente, sendo que, em algumas atividades, e em determinadas situações, mudam de minuto em minuto. Muitas vezes, os preços das commodities mudam no hiato de tempo existente entre a compra e a exportação, assim como entre o periodo entre o plantio e a colheita. Larson et alli (1998) ressaltam que estas características, obviamente, não são exclusivas do mercado de commodities, mas têm gerado e continuam provocando o desenvolvimento de uma classe especial de problemas e questões para os participantes do mercado e para vários formuladores de política. O problema da 
volatilidade dos preços e, portanto, da renda, é agravado pelo fato de que a maioria dos países produtores das commodities agrícolas é pobre.

Sabe-se da existência de um número considerável de commodities, porém, apenas algumas têm sido transacionadas em mercados futuros organizados. Uma das principais vantagens de transações em mercados futuros é que elas permitem que hedgers evitem os riscos de variações indesejadas de preços. Working (1953) definiu as transações de mercados futuros de commodities como transações conduzidas sob situações especiais de regulações e convenções, mais restritivas do que aquelas aplicadas a alguma outra classe de transações de commodities, que servem primariamente para facilitar a prática de operações de hedge e a especulação através de promoção de excepcional conveniência e economia de transação.

Telser e Higinbothan (1977) associam a vantagem da existência de um mercado futuro organizado à possibilidade de seus participantes poderem transacionar um contrato padronizado, tal que cada unidade de um contrato é um perfeito substituto para qualquer outra unidade. Tem-se ainda uma situação de eficiência, à medida em que a identidade das partes mutuamente acordadas na transação não afeta os termos de troca. Desta forma, um mercado futuro organizado cria um bem homogêneo que pode ser trocado em um mercado, no qual seus participantes são anônimos.

Em algumas situações existe o confronto entre políticas de sustentação de preços e mecanismos financeiros de proteção do risco. Gilbert (1985) discute a relevância da intervenção governamental para a estabilização de preços com relação à estabilização atingida via operações de hedge para o alcance do bem estar econômico. Ele afirma que vários autores têm sugerido que o teorema fundamental do bem estar exclui a intervenção. $O$ argumento que qualifica esta conclusão é o de que o governo tem acesso superior ao mercado de capitais e à informação, tendo que se considerar ainda que a estabilização pode resultar em redistribuição de renda, pois todos os agentes são afetados da mesma forma pelas variações dos preços, mas a estabilização pode beneficiar os produtores. Contudo, o referido autor enfatiza que os mercados futuros existem para muitas commodities primárias importantes, mas isto também está longe de satisfazer os 
pré-requisitos do teorema, desde que alguns agentes utilizam estes mercados existentes como substitutos daqueles que ainda não se formaram. Portanto, o número limitado de contratos futuros existentes sugere a invalidação do argumento de que a intervenção nos mecanismos de mercado nunca pode ser justificada em termos de aumento de bem estar econômico.

Gilbert (1985) conclui que se os agentes econômicos podem realizar transações a um baixo custo em mercados futuros não viesados, nos quais os contratos correspondem à produção ou consumo, os beneficios da eliminação dos riscos por meio de intervenção no mercado tende a zero. Isso porque os mercados futuros já possibilitam aos consumidores e produtores eliminarem os efeitos das variações não esperadas dos preços sobre suas utilidades. Contudo, isso só seria alcançado pelos agentes cuja produção tem efeitos desprezíveis sobre o preço da commodity. Em contrapartida, no caso dos grandes produtores, distúrbios na produção afetam o preço da commodity, de forma que não são capazes de eliminar completamente as incertezas sobre suas receitas. No entanto, podem adotar posições futuras que tornam as flutuações destas receitas estatisticamente independentes das variações do preço da commodity, pressupondo-se que eles estão mais interessados na estabilização de suas receitas.

A vantagem da utilização de mercados futuros, frente aos programas de sustentação de preços, pela ótica dos produtores, é que a rigidez dos preços gerada por políticas de sustentação pode tornar algumas transações inviáveis, e, portanto, comprometer parte do volume produzido, fato que não acontece com a utilização de mercados futuros. Com a possibilidade de utilização de hedge, os produtores escolhem a combinação ótima de preço e produção dentro de faixa de combinações viáveis.

Souza (1998) enfatiza a importância do desenvolvimento dos mercados futuros em economias emergentes pelos beneficios potenciais advindos desses mercados, tais como: transferência de risco de preço, sistema de formação de preços, melhoria de informação, redução dos custos de transação e coleta, maior número de vendedores e compradores e o desenvolvimento de uma infraestrutura financeira no país onde a bolsa foi instalada. 
Contudo, a criação de um mercado futuro bem organizado e que tenha sucesso é condicionada a determinadas pré-condições que o viabilizem. Tsetsekos e Varangis (1997) afirmam que as transações com derivativos entre os mercados de diferentes países são baseadas na idéia de serviços competitivos globais. O processo de globalização e mobilidade de capitais requer que os países tenham uma microestrutura comparável, pois se a função dos derivativos entre os países é a mesma, as estruturas institucionais locais são adaptadas para desempenhar essas funções. Estes autores presumem que em um ambiente de competitividade global, a microestrutura deve ser padronizada, de forma que chega a ser exogenamente especificada. Porém, na prática, tem-se observado que enquanto as funções dos derivativos são as mesmas em diferentes países, a estrutura institucional que permite o desempenho destas funções pode não ser uniforme entre as nações.

As peculiaridades da estrutura institucional que rege mercados eficientes pode prover a estes vantagens competitivas, que têm como consequências naturais a eliminação de informação assimétrica, facilidade de transação, motivação para negociação e possibilidade de descoberta de preço.

\subsection{Eficiência de Mercado versus Eficiência de Hedge}

Neste tópico procura-se discorrer sobre a diferença entre os conceitos de Eficiência de Hedge e Eficiência do Mercado Futuro. Enfatiza-se, também, a aplicabilidade dessas teorias e sua importância para o Mercado Futuro de commodities.

Os desenvolvimentos teóricos e empíricos já permitem afirmar que a administração de risco de preço e receitas envolvem a utilização de instrumentos de derivativos (Tomek \& Peterson, 2000). Na realidade, os economistas agrícolas vêm adotando com relativa frequência a teoria subjacente ao comportamento de preços de derivativos para aplicações em mercados de commodities. A teoria do comportamento dos preços em mercados eficientes é relativamente bem entendida, porém, a controvérsia 
persiste quando a questão consiste na eficiência dos mercados de derivativos para as diferentes commodities.

As evidências sugerem que boa parte dos mercados são relativamente eficientes, sendo que os prêmios associados a riscos são escassos e de baixo valor relativo. Isso significa, por sua vez, que os detentores dessas commodities não conseguem realizar lucros a partir de atividades especulativas baseadas nas mudanças de preços nos mercados de derivativos. Segundo Tomek \& Peterson (2000), alguns analistas acreditam, no entanto, que de maneira geral, o retorno médio das negociações pode ser aumentado através da utilização de mercados de futuros e opções.

O impasse que prevalece com relação às pesquisas que enfocam esse tópico pode ser sintetizado da seguinte forma: "a questão da eficiência de mercado é importante, mas não é evidente que os dados e métodos existentes permitem obter respostas úteis (Tomek \& Peterson, 2000). Isso se explica à medida em que muitos dos resultados de pesquisa relacionados à eficiência de mercado não representam uma contribuição expressiva em termos empíricos, para que os gargalos sejam devidamente identificados e superados. Para esses autores, o resultado de várias pesquisas relacionadas à eficiência dos mercados de derivativos pode ter sido pouco utilizado.

Tomek \& Peterson (2000) consideram ainda, que a discussão relativa à eficiência de mercados deveria ser conduzida de forma separada de análises que utilizam derivativos para precificar a produção, comercialização e retornos relativos à manutenção dos produtos como estoques. Em princípio, futuros e opções podem ser utilizados para assegurar um armazenamento mais (ou menos) rentável em anos em que prevalecem preços relativos favoráveis. As pesquisas requeridas para orientar tais decisões incluem projeções de relações de base e do risco de base. Em determinados casos, o risco de base pode ser muito elevado, de forma a tornar os derivativos ineficientes, sendo que essa é uma questão que também precisa ser melhor compreendida, a despeito da ampla literatura e trabalhos empiricos produzidos sobre o assunto. 
Vários trabalhos têm mostrado ainda, as diversas dificuldades relacionadas à distinção empírica dos conceitos de mercado eficiente e de mercado não viesado. A princípio, a eficiência de mercado traduz a condição de que os preços futuros, em tempo corrente, deverão igualar-se aos preços esperados do mercado spot para períodos futuros, devendo-se somar ou subtrair a esses valores um possível prêmio de risco, que pode ser variável ao longo do tempo.

Dessa forma, a hipótese de que os preços futuros proporcionam previsões não viesadas do preço spot constitui-se em uma hipótese conjunta de eficiência de mercado e neutralidade a risco (Mackenzie \& Holt; 1998). A questão pode se tornar ainda mais complexa pela dimensão de tempo, à medida em que os mercados podem ser eficientes e não viesados no longo prazo, mesmo apresentando ineficiências de curto-prazo.

É interessante que seja determinado ainda, o grau de eficiência entre os mercados de futuros, segundo esse conceito, tendo em vista que uma indicação quanto ao potencial destes em permitir que operações de hedge sejam efetivadas por estarem menos sujeitas a uma das três alternativas indicadas acima.

Arbex \& Carvalho (1999) também utilizaram o modelo de Eficiência de Mercado para testar a eficiência do mercado futuro do café brasileiro, sendo que, de acordo com estes autores, os resultados obtidos sugerem que no referido mercado, os preços futuros são estimadores não viesados dos preços à vista.

Portanto, enquanto o conceito de eficiência de mercado refere-se à condição de que os preços futuros devem se igualar aos preços esperados do mercado spot, para períodos futuros, mais ou menos um possível prêmio de risco, a eficiência de hedge diz respeito a quanto uma posiçấo tomada em mercados futuros permite reduzir a exposição ao risco de variaçăo de preços quando comparada com uma posição sem hedge.

Leuthold et alli (1989) enfatizam que a eficiência do hedging é medida comparando a variância do retorno de uma posição sem hedge com a variância do retorno de uma posição hedgeada. O procedimento indicado por esses autores fornece uma medida percentual da redução na variância após a realização de um hedge. 
Leuthold et alli (1989) afirmam que os resultados dos coeficientes de determinação $\left(R^{2}\right)$, de regressões lineares simples, que têm como variável dependente o preço no mercado à vista e como variável independente o preço futuro, indicam o grau de eficiência dos mercados futuros (do hedging). Dessa forma, quanto mais elevado for $o R^{2}$ mais eficiente é o mercado futuro.

No presente trabalho, as duas abordagens de eficiência serão testadas com intuito de se obter um parecer que seja qualitativo e que contribua para averiguação do desempenho do Contrato Futuro Cambial do Açúcar da BM\&F. As metodologias detalhadas de tais análises são apresentadas no capítulo 4 .

\subsection{Cross Hedging e Risco Residual Relativo}

Geralmente refere-se à realização de um hedge como uma proteção que se faz contra o risco de preço de uma determinada commodity atrelando-a a um contrato futuro, que tem como objeto a mesma commodity. Porém, como ressaltam Leuthold et alli (1989), para muitas commodities não há instrumentos de administração de riscos diretos, ou seja, a commodity não possui um correspondente mercado futuro.

Utilizam-se frequentemente, nestes casos, um cross hedging, que consiste em assumir uma posição em mercados futuros oposta à do mercado disponivel para uma commodity diferente daquela produzida ou utilizada pelo hedger. Mais especificamente, um cross hedging é uma posição tomada em mercado futuro de uma commodity que apresenta o comportamento de seu preço relacionado ao da commodity em questão.

Contudo, mesmo em casos em que existe um mercado futuro para a commodity, alguns autores reconhecem a importância do cross hedge. Derivando fórmulas operacionais para agentes econômicos preocupados com a média e variância de seus lucros, Anderson e Danthine (1981) enfatizam que nenhum dos estudos realizados anteriormente tratam explicitamente o cross hedging, de forma que não é considerada a idéia de mercados futuros múltiplos. Este autores afirmam que como os mercados à vista 
e futuro raramente são perfeitos substitutos, assim como a relação entre o preço à vista e preço futuro na data de entrega da commodity não pode ser prevista com exatidão (devido à existência do risco de base), dificilmente pode-se ter um hedge perfeito. Isto seria uma justificativa para se considerar uma abordagem de portfolio onde a redução do risco pode ser alcançada através da utilização de contratos múltiplos. O critério utilizado é a escolha de contratos melhores, para os quais são avaliados os benefícios associados com a existência de oportunidades alternativas de hedge.

Por outro lado, existem situações nas quais o cross hedge exibe uma eficiência superior à dos hedges diretos. Para Black (1986) um cross hedging é eficiente em reduzir o risco quando existe uma relação de dependência de preço entre a commodity a ser hegeada e o contrato futuro de outra commodity, ou ainda, da mesma commodity em outra bolsa. A existência de cross hedges eficientes pode ser uma das possíveis causas de fracasso de um determinado contrato futuro. O cross hedge eficiente relaciona o sucesso ou fracasso de um contrato futuro com a negociação de commodities proximamente relacionadas, ou de contratos futuros para a mesma commodity em diferentes bolsas. (Black, 1986)

A variável risco residual relativo, que leva em consideração o risco ao se optar por um hedge direto, ao invés do cross hedge, pode ser maior no primeiro do que no cross hedge. A escolha do hedger ficaria assim, condicionada ao contrato que apresentasse uma maior redução do risco residual. Considera-se como risco residual, o risco de permanecer em uma posição de hedge, quando comparado com o hedge perfeito. No caso em que se tem um hedge perfeito, todos o riscos são eliminados.

É importante ressaltar que sob essa suposição feita acima, não se considera as diferenças de custos de liquidez que os contratos alternativos podem apresentar, ou mesmo as diferenças dos custos de transação. Existem situações, no entanto, em que um novo contrato reduz o risco residual que os hedgers frequentemente incorrem. Contudo, a redução alcançada pode não ser suficiente para compensar os maiores custos de liquidez ou custos de transação deste novo contrato. 
Black (1986) utiliza como uma das ferramentas para avaliar o sucesso ou fracasso de um contrato futuro, a variável risco residual relativo. Esta é uma variável de incontestável importância para avaliação da abordagem do cross hedge eficiente. O risco residual relativo proporciona uma medida da redução do risco de mudança nos preços quando um contrato futuro direto é utilizado ao invés de se utilizar o cross hedge. Colocando de outra forma, o risco residual relativo compara o risco de own hedge com o risco do cross hedge para uma determinada commodity.

O foco central dessa proposta feita pela Black é avaliar quanto do risco existente ao se realizar um cross hedge pode ser reduzido, quando da mudança da realização de um cross hedge para um own hedge.

\subsection{Gerenciamento do Risco de Preço e Razão de Hedge}

Os agentes econômicos envolvidos no setor produtivo de commodity utilizam-se da prática de estocagem de seus produtos para vendê-los em um periodo futuro, visando aumentar seus lucros em decorrência de possíveis elevações dos preços dos respectivos bens. No entanto, é aconselhável que se faça uma proteção contra o risco de preço da commodity estocada. Os armazenadores, muitas vezes, realizando um hedge, tomam uma posição vendida no mercado futuro correspondente à sua posição comprada no mercado fisico. Todavia, Leuthold et alli (1989) ressaltam que volumes iguais nos dois mercados somente são apropriadas quando os preços spot e futuro tiverem coeficiente de correlação igual à unidade, ou quando suas variâncias forem iguais. É importante frisar, no entanto, que a constatação dessas condições não é comum devido a custos de carregamento e riscos de base.

Para demonstrar que a posição assumida no mercado futuro não tem necessariamente que ser igual à posição inversa assumida no mercado físico, Peck (1975) e Kahl (1983), utilizam técnicas de análise de regressão para calcular essas razões ótimas de hedge. A razão de hedge indica a parcela do volume da commodity 
estocada que deve ser hedgeada no mercado futuro. A pressuposição subjacente a essa técnica de estimação de mínima variância da razão de hedge é que esta minimiza a variância dos retornos para a posição combinada à vista/futuro.

No entanto, Lence et alli (1996) ressaltam que o modelo de razão de hedge de mínima variância não enfoca a questão da lucratividade, sendo que essa omissão é comumente justificada pelo fato de que os estudos empíricos têm permitido concluir que os preços futuros são não-viesados. Posto de outra forma, se os preços futuros são considerados não viesados, a lucratividade esperada de posições assumidas no mercado futuro é nula. Contudo, Lence et alli sugerem que mesmo sendo os preços futuros nãoviesados, eles não asseguram lucratividade nula nas posições assumidas no mercado físico. Isto ocorre, por exemplo, à medida em que a base ${ }^{6}$ se move de forma previsível ao longo de um determinado ano, ou ainda quando os custos de estocagem excedem o aumento esperado nos preços spot.

A Teoria Econômica sugere, segundo Lence et alli (1996), que os preços spot $\mathrm{e}$ futuros de commodities estocáveis comportam-se de forma previsível quando a oferta é grande no mercado à vista. Nessas condições, não se espera que o preço spot se mantenha abaixo do preço futuro por um montante superior aos custos de carregamento incorridos de estoques, porque as oportunidades de arbitragem seriam exploradas. Portanto, se o preço spot fica abaixo do preço futuro por um valor maior do que os custos de carregamento, lucros especulativos podem ser realizados comprando a mercadoria no mercado físico, vendendo contratos futuros e entregando a commodity no vencimento do contrato para cancelar a obrigação assumida no mercado futuro. De maneira inversa, ou seja, em uma situação de escassez de oferta no mercado à vista, o preço spot pode ficar bem acima do preço futuro, pelo menos teoricamente, desde que não haja oportunidade de ganho com a arbitragem de forma análoga ao caso anterior. Assim sendo, não se pode estabelecer um limite na diferença entre o preço spot e futuro, devido à falta de estoques, ou inviabilidade de estocar.

\footnotetext{
${ }^{6}$ Lence et alli (1996) definem base como sendo preço spot menos preço futuro.
} 
Desta forma, devido à assimetria no comportamento dos preços no mercado de futuro e o preço spot nos períodos de safra versus entre-safra da commodity, a covariância entre os preços spot e futuro provavelmente difere entre os dois cenários. Lence et alli afirmam que nesta situação, se a covariância for diferente entre estes dois períodos, a razão de hedge de mínima variância (calculada sem diferenciar as duas situações de mercado) pode não ser apropriada para o uso de modelos de estocagem. Como a razão de hedge é obtida através da razão entre a covariância do preço futuro e spot e a variância do preço futuro, somente a razão correspondente ao cenário de oferta deveria ser usada. Isto porque os autores acima citados afirmam que é razoável assumir que a realização do hedge, e portanto a lucratividade da estocagem, ocorrem quando a commodity é abundante.

Considerando-se a critica de Lence et alli (1996) passa a ser plausível a atenção que se deve dar ao custo de carregamento e às diferenças entre os preços futuro e spot no momento de se decidir qual parcela dos estoques deve ser hedgeada.

\subsection{Taxa de Juros e Custos de Carregamento}

O estudo das relações existentes entre os preços das commodities e variáveis macroeconômicas já preocupa pesquisadores há longa data. Keynes (1930) afirma que os negociantes ou produtores de commodities, dispostos a manter parte de seus estoques às custas de financiamento, são muito sensíveis a variações da taxa de juros. Quando as taxas de juros estão elevadas estes agentes são induzidos a reduzir seus estoques, ou do contrário, quando o mercado financeiro está favorável - baixas taxas de juros - procurase manter maior quantidade de estoques. Contudo, Keynes enfatiza a existência de custos de carregamento incorridos no periodo de armazenamento. Os custos de carregamento são divididos por esse autor da seguinte forma:

(i) risco de deteriorização, ou perda de qualidade da commodity estocada;

(ii) encargos de seguro e armazenamento; 
(iii) encargos dos juros; e

(iv) remuneração contra o risco de mudanças no valor monetário da commodity durante o tempo o qual ela ficou estocada, via financiamento.

Concomitantemente, Keynes (1930) afirma que os estoques causam uma forte pressão sobre o mercado, de forma que os preços são afetados. $O$ autor ressalta ainda que na presença de backwardation ${ }^{7}$ o preço spot deve exceder o preço futuro, e de forma oposta, se houver oferta de estoques, o preço futuro deve estar acima do preço spot para que sejam cobertos por esta diferença os custos da taxa de juros, armazenamento e depreciação. Este retomo que se obtém ao estocar determinada commodity, diferença entre os preços spot e futuro, é definido por Working (1949) como preço de estocagem, sendo que esse preço não é conhecido diretamente. Para Working o preço de estocagem é a diferença entre os preços de duas datas diferentes de entrega, de forma que esta diferença depende também do custo de carregamento.

Sem demonstrar por quais vias a taxa de juros de mercado afeta os preços das commodities, Satyanarayan e Varangis (1994) afirmam que produtos negociáveis podem deixar de ser negociados como ativos financeiros por causa do custo de oportunidade do dinheiro (taxa de juros). Eles afirmam que isto é particularmente verdadeiro para commodities que são mais estocáveis, tais como os metais. $\mathrm{O}$ alto índice de negociação das commodities implica que seus preços são mais sensiveis à variações da taxa de juros. Um estudo de Palaskas e Varangis (1989), citado por Satyanarayan e Varangis, encontrou que um aumento de um ponto percentual na taxa de juros reais leva a um decréscimo de $2,2 \%$ no preço spot dos metais, enquanto provoca uma diminuição no preço das commodities agrícolas menos estocáveis de somente $1,2 \%$.

Pela ótica dos produtores agrícolas ou dos armazenadores, sabe-se que o retorno que se obtém ao estocar certa commodity torna-se crucial na tomada de decisão entre as alternativas de estocar ou vender no presente. Por sua vez, considerando-se que a taxa de juros representa o custo de oportunidade do dinheiro em um determinado periodo de tempo, deve-se considerá-lo no processo de tomada de decisão. Moalla-Fettini (1990) 
conclui que existe para algumas commodities uma relação positiva entre taxa de juros reais e a taxa própria ${ }^{8}$ da commodity, ou seja, o retorno da commodity estocada. $O$ retorno obtido pela estocagem de determinada mercadoria também é enfatizado por Susmel e Thompson (1997). Para estes autores existe um prêmio por se estocar certo produto, que eles designam como "conveniência". Os beneficios da "conveniência" surgem da possibilidade de se aproveitar de demandas inesperadas ou choques de oferta. A Teoria da Estocagem desenvolvida originalmente por Kaldor (1939), citada por Susmel e Thompson (1997), implica que o preço futuro da commodity difere do preço spot pelo custo de estocagem, custos de oportunidade (taxa de juros) de se manter os estoques e o benefício da "conveniência", sendo contudo que o valor marginal da conveniência diminui quando o nível agregado dos estoques aumenta.

De forma similar, Barnhart et alli (1996) também definem as diferenças entre os preços de diferentes datas de entrega como sendo provenientes de custos de estocagem, taxa de juros livre de risco e da conveniência (convenience yield) ${ }^{9}$.

A teoria da estocagem também pode fornecer um importante link entre a taxa de juros e volume negociado de contratos futuros. De acordo com a teoria da estocagem, citada por Carter (1999), a relação de equilíbrio entre o preço futuro e o preço spot de determinada commodity estocável é dada pela seguinte expressão:

$F_{t, t+1}=S_{t}\left(1+r_{t, t+1}\right)+W_{t, t+1}(Q)-C_{t, t+1}$

Onde:

$F_{t, t+1}=$ preço futuro da commodity no período $t$ para entrega no periodo $t+I$;

$S_{t}=$ preço spot da commodity no período $t$;

$r_{t, t+1}=$ custo financeiro (custo de oportunidade de se manter estoques;

\footnotetext{
${ }^{7}$ Keynes (1930) define backwardation como uma situação em que não existem estoques.

${ }^{8}$ De acordo com Keynes, citado por Moalla-Fettini (1990), a taxa própria da commodity é igual a: q - c +1 , onde $\mathrm{q}=$ rendimento; $\mathrm{c}=$ custo de carregamento; $\mathrm{e} \mathrm{l}=$ premio de liquide $\mathrm{z}$.

${ }^{9}$ De acordo com Lozardo (1998) convenience yield funciona como um prêmio por se dispor do ativo quando este estiver em falta no mercado à vista.
} 
$W_{t, t_{+}+}(Q)=$ função custo fisico de estocagem, que engloba custos tais como despesas com armazenamento, seguros, etc., sendo $Q$ a quantidade física de estoques; e

$C_{t, t+1}=$ benefício obtido por se manter estoque do período $t$ ao período $t+1$, chamado de convenience yield.

Susmel e Thompson (1997) tratam a expressão (1) em termos de diferenças entre os preços spot e futuro de maneira que essa diferença deve-se também ao custo de estocagem, à taxa de juros (custo de oportunidade do dinheiro) e ao convenience yield, ou seja:

$F_{t, t+1}-S_{t}=S_{t}\left(r_{t, t+1}\right)+W_{t, t+1}(Q)-C_{t, t+1}$

A expressão (2) pode ser simplificada suprimindo $W_{t, t+1}(Q)$ e $C_{t, t+1}$. Lence et alli (1996) demostram que um do fatores que influencia a lucratividade ao se manter estoques e vender contratos futuros é o custo marginal da estocagem $\left(W^{\prime}(Q)\right)$ mas que a falta de dados a respeito dos custos de estocagem acaba sendo um fator limitante para a avaliação empírica desta variável. A simplificação passa a ser plausível ao se considerar um processo diário de arbitragem onde os custos de estocagem não variam na mesma velocidade em que os preços mudam. Com relação ao $C_{t, t+1}$, Moosa e Al-Loughani (1995) afirmam que como os participantes do mercado muitas vezes mantém estoques para cumprir os compromissos assumidos no mercado, ou simplesmente para arbitrar, a convenience yield pode tornar-se zero ou negligivel. Frankel (1984 e 1986) e Frankel e Hardouvelis (1985), citados por Moalla-Fettini (1990), também consideram desprezível o valor de $C_{t, t+1}$ para o modelo de determinação de preço futuro.

Fazendo tais suposições a expressão (2) pode ser colocada da seguinte forma:

$F_{t, t+1}-S_{t}=S_{t}\left(r_{t, t+1}\right)$ 
Trabalhando esta equação tem-se:

$$
\frac{F_{t, t+1}-S_{t}}{S_{t}}=r_{t, t+1}
$$

O lado esquerdo da expressão (4) fornece a taxa que o mercado futuro remunera a commodity no intervalo de tempo entre $t \mathrm{e}$ o período $t+1$. Portanto a equação (4) indica o equilíbrio entre a taxa própria da commodity e a taxa de juros de mercado.

Fazendo uma adaptação ao modelo apresentado por Moosa e Al-Loughani (1995) considera-se que seja possivel para o armazenador arbitrar utilizando os estoques de modo a garantir o equilíbrio da equação (4).

Moosa e Al-Loughani (1995) afirmam que a relação de preços spot/futuro é baseada na suposição de que os participantes do mercado são capazes transacionar nos mercados spot e futuro simultaneamente. Portanto, em uma situação de desequilibrio, na qual o lado esquerdo da expressão (4) fica maior do que o lado direito, ou seja, a taxa que o mercado futuro remunera a commodity é maior que a taxa de juros, os armazenadores podem arbitrar comprando commodity no mercado spot e assumindo posição vendida no mercado futuro até que o equilíbrio seja restabelecido.

Em uma situação oposta, os arbitradores podem vender commodity no mercado spot e comprar no mercado futuro, o que faria com que o preço spot diminuísse no mercado fisico restabelecendo a igualdade da expressão (4).

Desta forma um choque de taxa de juros que perturbe o equilibrio da equação (4) pode afetar o número de contratos futuros transacionados quando se assume a proposta de Working (1953 e 1954), citado por Black (1986), de que a maior parte do volume negociado de um contrato futuro deve-se ao montante de posições vendidas assumidas pelos hedgers. 


\section{METODOLOGIA}

Esse capítulo tem como objetivo apresentar a modelagem e os procedimentos utilizados para a condução dos propósitos dessa pesquisa.

\subsection{Análise da Eficiência de Mercado}

O procedimento a ser empregado para essa análise consiste na estimativa da relação entre as séries de preços nos mercados spot e futuro, conforme modelo desenvolvido a seguir, uma vez que as propriedades das séries temporais tenham sido analisadas e caracterizadas.

Conforme apresentado por Mackenzie \& Holt (1998), a arbitragem nos mercados permite estabelecer que, se os especuladores em mercados futuros são neutros ao risco, então o preço futuro corrente de uma commodity deve igualar-se ao preço spot esperado para período futuro, ou mais propriamente, o preço spot que deverá prevalecer por ocasião do vencimento do contrato. Essa condição pode ser ilustrada da seguinte forma:

$E_{\mathrm{t}-1} S_{\mathrm{t}}=F_{\mathrm{t}-1}$ 
onde $E_{\mathrm{t}-1} S_{\mathrm{t}}$ é a expectativa de preço spot, a prevalecer em periodo futuro, formada no período $t-1$, e $F_{\mathrm{t}-1}$ é o preço futuro relativo a contrato com vencimento no período $t$, em $t-1$.

Tomando como base essa especificação simplificada de eficiência de mercado é possível delinear um modelo adequado para o teste de eficiência de mercado. Assumindo-se que as expectativas são racionais, de forma que: $S_{\mathrm{t}}=E_{\mathrm{t}-1}\left(S_{\mathrm{t}} \mid \Omega_{\mathrm{t}-1}\right)+u_{\mathrm{t}}$, onde $\Omega_{\mathrm{t}-1}$ denota o conjunto de informações disponíveis no periodo $t-1, u_{\mathrm{t}}$ é o erro associado a expectativas racionais, e $u_{\mathrm{t}}$ é ortogonal a todos os elementos $\Omega_{\mathrm{t}-1}$, incluindo os erros de previsão defasados -, pode-se escrever a equação (5) da seguinte forma:

$$
S_{\mathrm{t}}=\alpha+\delta F_{\mathrm{t}-1}+u_{\mathrm{t}}
$$

Adicionalmente, a pressuposição conjunta da eficiência de mercado e ausência de viés constitui-se em uma implicação de restrições adicionais de que $\alpha=0$ e $\delta=1$. A equação (6) expressa, portanto, um modelo que pode ser estimado por regressão linear simples, que permite conduzir testes para a eficiência de mercado e ausência de viés.

Deve-se atentar, no entanto, que três conclusões mutuamente exclusivas podem ser associadas à rejeição da hipótese nula nos testes da significância estatística desses parâmetros: (i) o mercado pode ser, de fato, ineficiente; (ii) existe um prêmio constante pelo risco, o que faz com que as previsões de mercado possam ser eficientes, ainda que viesadas ( $\alpha_{\text {cte }}$ diferente de zero); e (iii) existe a possibilidade de que o prêmio relativo ao risco seja inerente ao mercado, ainda que variável ao longo do tempo, impossibilitando que os preços futuros proporcionem, de forma isolada, previsões não viesadas sobre o preço spot relativo a períodos futuros (ou seja, ineficiente devido ao viés intrínseco).

O objetivo do presente trabalho consiste em aplicar procedimentos que permitam identificar, por meio da análise empírica, dentre essas possíveis conclusões, aquela que melhor se aplica ao mercado de futuros de açúcar da BM\&F. Para isso, compara-se o 
grau de eficiência com os mercados futuros da CSCE e LIFFE, tendo em vista que essas últimas têm sido consideradas como alternativas para um hedger brasileiro.

É interessante determinar ainda o grau de eficiência entre os mercados de futuros, segundo esse conceito, considerando-se o potencial destes em permitir que operações de hedge sejam efetivadas por estarem menos sujeitas a uma das três alternativas indicadas acima.

Tem sido amplamente argumentado na literatura que os testes apropriados para avaliar a eficiência de mercado e a ausência de viés dependem das características de estacionariedade $^{10}$ dos dados. Ou seja, se as séries de preços são não-estacionárias, testes de hipóteses baseados na equação (6) apresentariam resultados viesados. A análise de regressão empregando variáveis não estacionárias geralmente conduz a problemas de regressão espúria, sendo que inferências a partir de testes de hipótese $t$ de Student e F deixam de ser válidos. Nesses casos, o pesquisador pode concluir de forma errônea que existe uma relação entre duas séries não estacionárias que não são, de fato, relacionadas.

A abordagem utilizada para a obtenção das estimativas para a análise de eficiência de mercados futuros na presente análise, toma como base um procedimento empregado por Beck (1994), citado por Mackenzie \& Holt (1998), que conduziu teste semelhante de eficiência voltado a diversos mercados futuros de commodities.

De acordo com Mackenzie \& Holt (1998), Beck parte do seguinte princípio: se ambas as séries de preços spot e futuros apresentarem-se não estacionárias, torna-se dificil identificar a estacionariedade pela simples combinação linear das séries. $\mathrm{Na}$ equação (7), por exemplo, tem-se a especificação de uma série estacionária, sendo que $\alpha$ e $\delta$ são os termos de co-integração. Dessa forma, conforme indicado anteriormente, a regressão correspondente à equação (6) refere-se a uma regressão de equilíbrio ou de cointegração, expressa como:

\footnotetext{
${ }^{10}$ Uma apresentação detalhada dos procedimentos utilizados na condução de testes quanto às propriedades das séries temporais é apresentada no Anexo.
} 
$u_{\mathrm{t}}=S_{\mathrm{t}}-\alpha-\delta F_{\mathrm{t}-1}$

De acordo com a equação (7), se $u_{\mathrm{t}}$ é um processo estacionário, $S_{\mathrm{t}}$ e $F_{\mathrm{t}-1}$ não podem divergir muito entre si, mesmo quando ambas as séries apresentam-se não estacionárias. Dessa forma, a co-integração entre as duas séries é uma condição necessária para identificar a eficiência de mercado. Diversos autores consideram, no entanto, que tal co-integração constitui-se, de fato, em condição necessária, porém não suficiente para concluir quanto à eficiência dos mercados futuros (McKenzie \& Holt, 1998).

McKenzie \& Holt (1998) afirmam que os preços spot (mercado à vista) e do mercado futuro são determinados pelos mesmos fundamentos, de forma que a condição de eficiência implica que esses não podem divergir muito entre si ao longo do tempo. No entanto, a existência de relação de co-integração não implica que ineficiências de curto prazo não ocorram, dado que a informação defasada, obtida a partir de mercados futuros, pode melhorar progressivamente a previsão relativa aos preços spot a prevalecerem em períodos futuros.

Um modelo de série temporal envolvendo variáveis co-integradas pode ser expresso na forma de um modelo de correção de erros, conforme Granger (1986), citado por Rao (1994). Esta transformação torna a série estacionária, conforme se discute no Anexo, permitindo a realização de testes de hipóteses normais. O modelo de correção de erros, correspondente à equação (6) pode ser representado da seguinte forma:

$$
\Delta S_{t}=-\rho u_{t-1}+\beta \Delta F_{t-1}+\sum_{i=2}^{m} B_{i} \Delta F_{t-i}+\sum \psi_{j} \Delta S_{t-j}+v_{t}
$$

onde $\Delta$ define a diferença da variável de um periodo ao próximo, $u_{\mathrm{t}}$ é o termo de correção de erros e $v_{\mathrm{t}}$ é a série estacionária, $\mathrm{i}$ - número de defasagens incluídas para os preços do mercado futuro, tomados nas suas diferenças; $j$ - número de defasagens 
incluídas relativas ao mercado spot em diferenças, sendo que todas as outras variáveis já foram definidas anteriormente.

O modelo de correção de erros apresentado na equação (8) tem como objetivo verificar a existência de desequilibrios que podem gerar ineficiências de curto-prazo, uma vez que todas as informações disponíveis foram incorporadas.

A existência de co-integração implica em $\rho>0$ desde que as mudanças no preço spot respondam a desvios de equilíbrio de longo-prazo relativo à equação (6). A eficiência de mercado implica que: $\rho=1 ; \rho \delta=\beta \neq 0$; e $B_{i}=\Psi_{i}=0$.

O coeficiente $\beta$ é diferente de zero para mudanças correntes nos preços futuros, tendo em conta que novas informações, que também afetam os preços futuros, devem afetar mudanças futuras no preço spot.

Restrições adicionais podem ser melhor compreendidas reescrevendo a equação (8), introduzindo a equação (7) conforme se apresenta a seguir, ou seja, onde o $u_{t-1}$ é substituído por $\left(S_{\mathrm{t}-1}-\alpha-\delta F_{\mathrm{t}-2}\right)$, resultando em:

$$
S_{t}=(1-\rho) S_{t-1}+\beta F_{t-1}+(\rho \beta-\beta) F_{t-2}+\rho \alpha+\sum_{i=2}^{m} B_{i} \Delta F_{t-i}+\sum_{j=1}^{k} \psi_{j} \Delta S_{t-j}+v_{t}
$$

Verifica-se, portanto, que se as restrições especificadas acima não são válidas empiricamente, tanto os preços futuros, tomados com defasagens, como no mercado à vista (spot), contêm informações relevantes que não foram completamente incorporadas nos preços futuros, tomados em tempo corrente, que poderiam ser utilizadas para prever no período $t-1$, o preço no mercado spot $S$, no período $t$.

A hipótese de eficiência de mercados estabelece que toda a informação passada deve ser incorporada nos preços futuros em tempo corrente, de forma a não afetar o preço spot que prevalecerá em período futuro.

Beck (1994), citado por McKenzie \& Holt (1998), afirma que os testes de eficiência baseados na equação (8) e nas restrições especificadas acima permitem a 
existência de um risco de prêmio constante. Isso se deve ao fato de que as pressuposições empregadas ao utilizar a equação (6) para o teste de eficiência de mercados futuros, não se aplicam quando os testes relacionados à equação (8) são estabelecidos $^{11}$.

Dessa forma, assumindo-se que o prêmio de risco é constante e não varia ao longo do tempo, pode-se testar as duas hipóteses separadamente, ou seja, de eficiência e inexistência de viés, respectivamente.

De acordo com McKenzie \& Holt (1998), Beck (1994) aplicou o teste a vários mercados de futuros. A hipótese de que não existe viés de curto prazo é examinada utilizando um modelo de correção de erros, conforme o que é apresentado na equação (8), e conduzindo testes para averiguar as seguintes restrições:

$$
\rho=1 \quad \beta=1 \quad B_{i}=\Psi_{i}=0
$$

O teste de hipótese de eficiência de mercado no sentido fraco, compreende, por sua vez, o teste das seguintes restrições:

$$
\rho=1 \quad \beta=\delta \quad B_{i}=\Psi_{i}=0
$$

A pressuposição de que $\alpha=0$ e $\delta=1$ pode ser testada utilizando o procedimento de co-integração de Engle e Granger. O detalhamento dessa abordagem é apresentado no Anexo.

Segundo Mckenzie \& Holt (1998), pode-se inferir quando prevalecem ambas as características, eficiência de mercado e inexistência de viés, dentro de um contexto de

\footnotetext{
${ }^{11}$ As pressuposições equivalem à consideração de que $\alpha=0$ e $\delta=1$.
} 
longo-prazo, de forma que não se pode rejeitar a hipótese de que $\alpha=0$ e $\delta=1$. Nesse caso, a equação (7) reduz-se a:

$u_{\mathrm{t}}=S_{\mathrm{t}}-\delta F_{\mathrm{t}-1}$

Nesse trabalho realizar-se-á somente os testes referentes à hipótese de eficiência de mercado e ausência de viés em um conceito de longo-prazo, expressão (7). Isso porque, acredita-se que como o objetivo dessa pesquisa é conduzir uma análise comparativa entre os mercados futuros, em termos de eficiência para um hedger nacional, resultados referentes a análises de curto-prazo não trazem informações adicionais relevantes para a referida comparação investigada no estudo em questão. Portanto, a realização dos testes propostos permite inferir quanto à existência ou não de um prêmio de risco no longo-prazo, em se constatando que ambos, ausência de viés e eficiência de longo-prazo se aplicam ao mercado. Isso permite, dessa forma, ter-se uma indicação, em termos relativos, quanto à possibilidade de que a efetivação de um hedge em determinado mercado seja relativamente mais favorável que em outro, em se constatando a inexistência de um prêmio de risco de longo-prazo.

\subsection{Comparação da Eficiência de Hedge na BM\&F, CSCE e na LIFFE}

Neste tópico apresenta-se uma proposta para determinação da eficiência do mercado futuro do açúcar na BM\&F de forma que se possa comparar essa medida com aquelas que serão também mensuradas, nesta pesquisa, para o mercado futuro da CSCE e da LIFFE.

A eficiência de hedge parte do princípio do comportamento individual do agente econômico racional que busca maximizar sua utilidade, o que é expresso por Leuthold et alli (1989), da seguinte forma: 
$\operatorname{Max} E(U)=E\left(R_{p}\right)-\lambda 2 \operatorname{Var}\left(R_{p}\right)$

onde:

$E(U)=$ esperança da utilidade;

$E\left(R_{p}\right)=$ retorno do portfolio;

$\lambda=$ parâmetro de aversão ao risco; e

$\operatorname{Var}\left(R_{p}\right)=$ variância do retorno do portfolio.

Para um indivíduo representativo que busca o retorno ótimo dentre duas possíveis posições - Mercado Spot e Mercado Futuro -, Leuthold et alli sugerem a aplicação da Teoria do Portfolio, de acordo com o modelo representado abaixo:

$$
E\left(R_{p}\right)=X_{s} E\left(R_{s}\right)+X_{f} E\left(R_{f}\right)
$$

onde:

$X_{s}=$ montante de posições à vista (spot);

$X_{f}=$ montante de posições em futuros;

$E\left(R_{s}\right)=$ retorno esperado da posição à vista, ou $E\left(S_{l}\right)-S_{0}$;

$E\left(R_{\mathcal{D}}\right)=$ retorno esperado da posição em futuros, ou $E\left(F_{l}\right)-F_{0}$;

sendo que o risco de manter essa alocação pode ser expresso de acordo com a variância dos retornos, como segue:

$V\left(R_{p}\right)=X_{s}^{2} \sigma_{s}^{2}+X_{f}^{2} \sigma_{f}^{2}+2 X_{s} X_{f} \sigma_{s f}$

onde:

$\sigma_{s}^{2}=$ variância do retorno da posição à vista (mudança no preço);

$\sigma_{f}^{2}=$ variância do retorno da posição no mercado futuro (mudança no preço); 
$\sigma_{s f}=$ covariância das variações dos retornos (mudanças nos preços à vista e futuro).

Conforme mostra a equação (11), maximizar a utilidade é equivalente a maximizar a expressão $E\left(R_{p}\right)-\lambda / 2 \operatorname{Var}\left(R_{p}\right)$. Na abordagem de portfolio com dois ativos esta pode ser expressa da seguinte forma:

$X_{s} E\left(R_{s}\right)+X_{f} E\left(R_{j}\right)-\lambda / 2\left(X_{s}^{2} \sigma_{s}^{2}+X_{f}^{2} \sigma_{f}^{2}+2 X_{s} X_{f} \sigma_{s f}\right)$

O modelo apresentado por Leuthold et alli (1989) nessa etapa, parte para a determinação da posição ótima, em mercados futuros, que deve ser assumida pelo hedger ao se considerar a posição à vista como exógena. A posição ótima ${ }^{12}$, portanto, é definida de acordo a expressão:

$$
X_{f}^{*}=\frac{E\left(F_{1}\right)-F_{0}}{\lambda \sigma_{f}^{2}}-X_{s} \frac{\sigma_{s f}}{\sigma_{f}^{2}}
$$

A equação (15) é a soma de dois componentes a saber:

$$
H_{1}=\frac{E\left(F_{1}\right)-F_{0}}{\lambda \sigma_{f}^{2}}
$$

conhecido como componente especulativo, e;

\footnotetext{
${ }^{12}$ Como o objetivo dessa pesquisa não é a determinação da razão ótima de hedge, não foi explanado aqui detalhes dessa passagem. Para a derivação detalhada da razão ótima de hedge, ver apêndice do Capitulo 5 de Leuthold et alli (1989). A razão de hedge ótima é obtida através da determinação de $b^{*}=X_{f} X_{s}$.
} 


$$
H_{2}=-X_{s} \frac{\sigma_{s f}}{\sigma_{f}^{2}}=-X_{s} r \frac{\sigma_{s}}{\sigma_{f}}
$$

que é a razão ótima de hedge, onde $r$ denota o coeficiente de correlação entre os preços à vista e futuros da commodity. Porém, uma proposta alternativa seria a de minimização da expressão (13) através da utilização de mercados futuros $\left(X_{f}\right)$, chegando-se a:

$$
\frac{\partial \sigma_{p}^{2}}{\partial X_{f}}=2 X_{f} \sigma_{f}^{2}+2 X_{s} \sigma_{s f}=0
$$

e, portanto isolando-se $X_{f}$, tem-se:

$$
X_{f}^{*}=-X_{s} \frac{\sigma_{s f}}{\sigma_{f}^{2}}
$$

Supondo-se, em (19) $X_{s}=1$, para determinação em termos relativos, e substituindo $X_{f}^{*}$ em (13) chega-se a:

$$
V\left(R_{p}\right)=\sigma_{s}^{2}-\frac{\sigma_{s f}^{2}}{\sigma_{f}^{2}}
$$

A equação (20) expressa a variância mínima, com a utilização de mercados futuros, para a redução de risco do agente econòmico.

Finalmente, pode-se chegar a uma medida de redução de risco, através do modelo de portfolio, comparando a variância do retomo de uma posição não hedgeada 
com a variância do retorno da posição envolvendo a realização do hedging. Desta forma, Leuthold et alli (1989) apresentam uma medida de eficiência de hedge, $E^{*}$, como uma percentagem de redução na variância com a utilização de futuros, ou seja:

$$
E^{*}=\frac{\operatorname{Var}(S)-\operatorname{Var}\left(R_{p}\right)}{\operatorname{Var}(S)}=1-\frac{\operatorname{Var}\left(R_{p}\right)}{\operatorname{Var}(S)}
$$

onde:

$\operatorname{Var}\left(R_{p}\right)=$ variância do portfolio com minimização do risco; e $\operatorname{Var}(S)=$ variância associada a uma posição sem hedge.

Portanto, substituindo (20) em (21) tem-se:

$$
E^{*}=\frac{\sigma_{s f}^{2}}{\sigma_{s}^{2} \sigma_{f}^{2}}
$$

No contexto de análise de regressão, a variável $E^{*}$ da expressão (22) é o próprio coeficiente de determinação ${ }^{13}$, podendo ser desta forma mensurado através do $R^{2}$ da seguinte regressão, e que será utilizada no presente trabalho:

$\Delta S_{t}=\alpha_{i t}+\beta_{i t}\left(\Delta F_{i t}\right)+\varepsilon_{i t}$

onde:

$\Delta S_{t}=$ variações diárias de preços no mercado disponivel brasileiro da commodity açúcar; $\Delta F_{i t}=$ variações de preços futuros do açúcar, na bolsa $i$;

$\alpha_{i t}$ e $\beta_{i t}=$ parâmetros a serem estimados; $\mathrm{e}$ $\varepsilon_{i t}=$ termo de erro. 
Portanto, a regressão acima será estimada para que se possa fazer a comparação da eficiência do hedging para o hedger brasileiro, do setor sucroalcooleiro, que pode se proteger de variações de preço do açúcar assumindo posições nos mercados futuros da BM\&F, CSCE ou LIFFE. O objetivo dessa análise é buscar mais uma ferramenta para a análise de possíveis entraves da utilização do Contrato Futuro Cambial do Açúcar Cristal da BM\&F. O mercado disponivel considerado para a análise será somente o brasileiro, sendo que quanto mais alto o valor do coeficiente de determinação da regressão para cada bolsa, maior será a eficiência desta em proteger o hedger nacional contra variações inesperadas de preços.

Em todas as etapas dessa pesquisa serão feitos testes estatísticos para certificação das propriedades desejáveis das séries temporais, tal como estacionariedade, a fim de se precaver de regressão espúria. O procedimento para o teste de estacionariedade é discorrido no tópico 4.7 , deste capítulo.

\subsection{Risco Residual Relativo}

Um refinamento do modelo de eficiência de hedge, apresentado no tópico 4.3 é a construção da variável risco residual relativo, que será baseada em proposta sugerida por Black (1986). Como visto na sessão anterior, a autora também ressalta que uma medida comum da redução do risco em portfolio hedgeado é o coeficiente de determinação $\left(R^{2}\right)$ da regressão que tem como variável dependente a variação do preço spot e como variável explicativa, a variação do preço futuro, expressão (23). No caso de um hedge perfeito o coeficiente de determinação é igual a 1 , indicando que o risco residual de um portfolio hedgeado pode ser expresso como sendo igual a $\left(l-R^{2}\right)$. Souza (1998) afirma que $\left(l-R^{2}\right)$ é igual à variância do portfolio com hedge dividido pela variância do portfolio sem hedge, de forma que expressa a proporção do risco total incorrida pelo

\footnotetext{
${ }^{13}$ Gujarati (1995) demonstra que o $R^{2}=\left(\sum x_{i y}\right)^{2}\left(\sum x_{i}^{2} \sum y_{i}^{2}\right)$, onde $x_{i}$ e $y_{t}$ são variáveis centradas.
} 
tomador de decisão, que seria associada à tomada de sua posição, pelo hedger, no mercado futuro.

Para o caso da commodity açúcar, objeto dessa pesquisa, a medida do risco residual relativo requer para seu cômputo:

(i) o risco residual do cross hedging; e

(ii) risco residual do own hedging.

Black (1986) afirma que o primeiro passo é estimar a relação entre os preços no mercado disponível e futuros, de acordo com a equação (23).

Os contratos utilizados no cômputo de $\Delta F_{i}$ serão os contratos próximos do mês de vencimento. Souza (1998) afirma que esses contratos devem ser utilizados por refletirem o momento em que os hedgers estão mais dispostos a negociá-los.

O coeficiente de determinação $\left(R^{2}\right)$ da expressão (23) é usado como medida de redução de risco para a commodity açúcar na bolsa $i$. No caso de se ter um hedge perfeito o $R^{2}$ da equação (23) seria igual a (1). Portanto $\left(I-R^{2}\right)$ refere-se à medida de risco que permanece após a realização de uma operação com contrato futuro, ou seja, o risco residual.

A variável risco residual relativo, a ser calculada, expressa a razão do risco residual do cross hedge pelo risco residual do own hedge da commodity. Souza (1998) afirma que se o risco residual relativo for maior do que 1 , significa que o cross hedge carrega mais risco do que o own hedge. Desta forma, o mercado de own hedge seria preferido ao mercado de cross hedge, o que levaria a um aumento no volume transacionado de contratos futuros no mercado de own hedge.

As estratégias de hedging referente às possibilidades de cross hedges a serem testadas encontram-se resumidas na Tabela 5.

Black (1986) enfatiza que uma maneira mais simples de definir a variável risco residual relativo é em termos de variâncias. A autora afirma que: 
$R^{2}=1-\frac{\operatorname{Var} R^{*}}{\operatorname{Var} U}$

onde:

$\operatorname{VarR}^{*}=$ variância de um portfolio que inclui a tomada de uma posição em mercados futuros, a qual minimiza a variância; e

$\operatorname{Var} U=$ variância de um portfolio sem hedge.

Assim sendo, tem-se que:

$1-R^{2}=\frac{\operatorname{Var} R^{*}}{\operatorname{Var} U}$

onde:

$1-R^{2}=$ proporção do risco do portfolio sem hedge que permanece depois da execução do hedging.

Tabela 5. Mercados de own hedge e de cross hedges selecionados.

\begin{tabular}{ccc}
\hline Mercado Disponível (Local) & Mercado Futuro (Bolsa) & Cross hedge (Bolsa) \\
Açúcar (Brasil) & BM\&F & CSCE \\
Açúcar (Brasil) & BM\&F & LIFFE
\end{tabular}

Denominando os portfolios de hedging como:

$R_{o}^{*}$ para o own hedging; e

$R_{c}^{*}$ para o cross hedging;

seus riscos residuais são, respectivamente: 
$\frac{\operatorname{VarR}_{o}^{*}}{\operatorname{Var} U}$ e $\frac{\operatorname{VarR}_{c}^{*}}{\operatorname{Var} U}$

Black (1986) ressalta que como não se está interessado na proporção do risco do portfolio sem hedge que surge depois da tomada de uma posição de hedging, a análise focaliza-se sobre a comparação de duas estratégias de hedging, ou seja, na comparação do own hedging com o cross hedging. Portanto calcula-se a variável risco residual relativo $\left(R R_{i}\right)$ como segue:

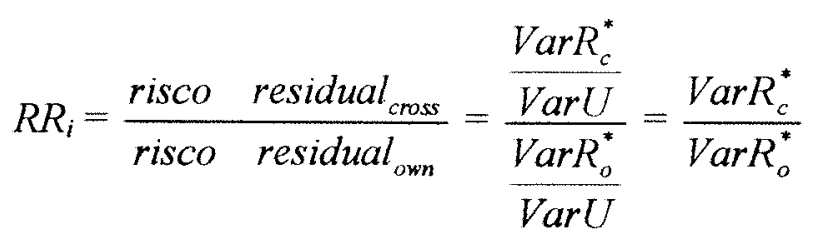

Esta medida relativa fornece a informação de quanto do risco surge quando o cross hedge é utilizado ao invés de se utilizar o own hedge. Black afirma ainda que pode-se especificar o efeito esperado da variável risco residual relativo em sua forma empírica. Para valores grandes $(>1)$ significa que o cross hedging expõe o hedger a muito mais risco do que o own hedge. Assim espera-se que os hedgers prefiram muito mais o own hedge, que no caso seria a negociação na BM\&F. Valores baixos (próximos de 1) para a variável risco residual relativo indica que o risco do cross hedge é similar ao risco do own hedge, e portanto se considerar-se apenas o fator risco, os hedgers seriam indiferentes sobre qual mercado utilizar. Finalmente, valores muito baixos para a variável em questão $(<1)$ indicam que o cross hedging sujeita um hedger a muito menos risco do que o own hedging. 


\subsection{Grau de Associação entre o Diferencial Taxa de Juros e Taxa Própria e o Volume de Negociação do Contrato Futuro Cambial do Açúcar da BM\&F}

Nesta sessão apresenta-se a metodologia a ser utilizada para a mensuração do grau de associação existente entre o diferencial que há entre a taxa de juros de mercado e a taxa pela qual o mercado futuro remunera o açúcar e o volume de negociação do contrato futuro. Parte-se da pressuposição de racionalidade do tomador de decisão do setor sucroalcooleiro, ou seja, considera-se que o agente fará a escolha inter-temporal entre estocar o produto e vender em um período futuro, ou vender no mercado à vista. Caso venha vender em um período futuro, espera-se que esse agente, o faça através de um hedge no Mercado Futuro do Açúcar, commodity foco da referente análise. Desta forma, pressupõe-se que os agentes econômicos que realizam um hedge no mercado futuro, para assegurar ganhos com a estocagem, estejam levando em consideração o patamar de taxa de juros doméstica, que reflete o custo de oportunidade do dinheiro da economia, e portanto pode onerar os custos de carregamento conforme citado no Capítulo 3, tópico 3.5.A hipótese a ser testada é de quanto maior o diferencial entre as taxas, maior será o volume de negociação. Satyanarayan e Varangis $(1994)^{14}$ ressaltam que o retorno para uma commodity deve incluir o custo de oportunidade do dinheiro, sendo que este seria representado por uma taxa de juros livre de risco. De forma não muito diferente, a taxa de juros considerada para determinar o preço futuro, como indica Lozardo (1998), deve ser uma taxa de juros livre de risco.

Lozardo parte do princípio de que o preço à vista é o preço futuro descontado de uma taxa de juros livre de risco, desconsiderando-se os outros custos de carregamento. $\mathrm{O}$

\footnotetext{
${ }^{14}$ Estes autores afirmam que a relevância de se considerar, no cômputo do retorno de commodity, o custo de oportunidade do dinheiro pode ser evidenciado pela forma como é calculado o indice de commodity disponibilizado pela empresa de consultoria Goldman Sachs, a qual utiliza três componentes na construção do indicador, os quais são:

(i) o retorno dos títulos da dívida pública americana, chamados T-bills, que indicam o custo de oportunidade do dinheiro;

(ii) o retorno spot, que é simplesmente a mudança no preço da commodity; e

(iii) o beneficio de negociar contratos futuros
} 
modelo de determinação do preço do contrato futuro, apresentado pelo autor supracitado, seguindo o conceito de custo de carregamento, tem a seguinte forma:

$F=P(I+i)^{t}+C$

onde:

$F=$ Preço futuro a ser pago, na data do vencimento do contrato;

$P=$ Preço à vista;

$i=$ taxa de juros;

$t=$ número de dias úteis entre a data da operação e de vencimento do contrato futuro; e $C=$ valor presente dos custos de carregamento.

Considerando-se que os mercados futuros de commodities são mercados competitivos, de forma que os preços para cada agente tomado individualmente são dados, e suprimindo os outros custos de carregamento, pode-se calcular através de (28) a taxa própria da commodity. Suprimindo-se o $(C)$ da equação (28), em um conceito de fluxo de caixa, para dado valor de $P$ e $F$, tem-se num determinado período de tempo, a taxa interna gerada pela diferença entre $P$ e $F$. Essa taxa $(r)$ é a taxa que o mercado futuro, com preço $F$, remunera a commodity cotada no mercado spot ao preço $(P)$. Portanto, através da expressão (28), pode-se encontrar a taxa diária em que o mercado futuro remunera determinada commodity durante o número de dias (úteis) existente entre a data da operação e o período de vencimento do contrato. Dessa forma tem-se que:

$r=\left[(F / P)^{1 / t}-1\right]$

onde:

$r=$ taxa que o mercado futuro remunera o açúcar.

Para que o $(r)$ seja expresso em valores percentuais mensais, considerando-se dias úteis, tem-se: 
A variável que expressa o diferencial $(d)$ entre a taxa de juros de mercado mensal (i) e a taxa $(r)$ encontrada na expressão (29), pode ser calculada como:

$d=r-i$

Proceder-se-á então a uma análise de correlação entre o volume de negociação do contrato $[V]$ e o diferencial $[d]$. Souza (1998) e Black (1986) afirmam que tanto o volume de negociação de um contrato quanto o número de contratos em aberto servem como critério de avaliação do patamar de utilização de um determinado contrato futuro. Nesta pesquisa, referir-se-á ao volume de negociação do Contrato Futuro Cambial do Açúcar como sendo o número de posições em aberto. Desta forma, pode-se formalizar a análise de correlação tal como segue:

$\rho=\operatorname{corr}(V ; d)$

onde $\rho=$ coeficiente de correlação entre $V e d$.

Sendo que os valores de " $V$ " e " $d$ " serão tomados em suas médias semanais.

Dada a possibilidade de se obter estimativas viesadas do verdadeiro valor de $\theta$ (Coeficiente de correlação da população), Hoel (1971) sugere a utilização de um teste estatístico para verificar o resultado amostral do coeficiente de correlação. Mattos (2000) utilizou o teste sugerido por Hoel (1971) testando a seguinte hipótese:

$H_{0}: \rho=0 \quad H_{A}: \rho \neq 0$

\footnotetext{
${ }^{15}$ Schouchana (1997) também utiliza essa expressão para avaliar a viabilidade financeira de determinada usina vender em um periodo futuro vis a vis realizar a venda no mercado disponivel. Comparando o resultado com o custo de oportunidade do capital.
} 
Sendo a estatística $t$ utilizada para testar a hipótese nula apresentada na expressão (33), ou seja, isto pode ser feito através da seguinte equação:

$$
t_{\text {cal }}=\frac{\rho \sqrt{n-2}}{\sqrt{1-\rho^{2}}}
$$

Onde:

$t_{c a l}=t$ calculado que será comparado com estatística $t$ para verificação da hipótese nula;

$\rho=$ coeficiente de correlação da amostra; e

$n=$ número de observações da amostra.

Desta forma, para um determinado nível de significância, a hipótese de correlação nula não pode ser rejeitada se o valor calculado de $t$ for menor do que o valor crítico ( $t$ tabelado). Se o valor de $t_{c a l}$ for maior do que $t$ tabelado, para um determinado nível do confiança, rejeita-se a hipótese nula e aceita-se a hipótese alternativa. Portanto, nesse caso, o coeficiente de correlação, ou seja o grau de associação linear entre as variáveis " $V$ " e " $d$ " existirá ao nível de significância estatística determinado.

\subsection{Fonte dos Dados}

Os dados para a análise do presente trabalho referentes aos preços futuros e ao volume de contratos negociados (número de contratos em aberto) do açúcar foram obtidos junto à BM\&F. Para os preços spot utilizou-se o indicador ESALQ/BM\&F construído pelo Centro de Estudos Avançados em Economia Aplicada (CEPEA/ESALQ). Os dados relativos à taxa de juros doméstica foram extraídos da Revista Juros \& Moedas. Por fim, os preços futuros e spot do açúcar de Nova Iorque e Londres foram também obtidos junto à BM\&F. 
O periodo analisado, nesse trabalho, será de 14/04/1997 até 28/07/2000, quando o Contrato Futuro Cambial do açúcar da BM\&F foi extinto. Não será utilizado o período desde o lançamento do contrato (setembro de 1995) porque foi mudado o procedimento de cálculo do indicador de preço do açúcar no mercado disponível (spot), o qual ganhou nova fórmula a partir de 14 de abril de 1997.

As variáveis propostas para elaboração da presente análise estarão computadas em suas médias semanais. 


\section{RESULTADOS E DISCUSSÃO}

\subsection{Eficiência dos Mercados Futuros}

A análise empírica relativa à eficiência de mercados futuros foi conduzida em duas etapas. A primeira apresenta uma caracterização das propriedades das séries temporais quanto à sua estacionariedade, ou seja, quanto ao número de raízes unitárias.

Nessa primeira etapa foram investigadas e caracterizadas as propriedades das séries temporais empregadas na análise, incluindo-se o preço do mercado spot doméstico, representado pelo Indicador de Açúcar Cristal ESALQ/BM\&F, e pelas séries de cotações de futuros de açúcar na BM\&F, na CSCE (contrato no 11 ) e na LIFFE (contrato $\mathrm{n}^{\circ} 5$ ). As séries de dados dos preços futuros foram compostas considerando-se o encadeamento das cotações sempre referentes ao próximo vencimento. Todos os dados utilizados foram convertidos em suas médias semanais.

A segunda etapa foi desenvolvida tomando-se como base os resultados obtidos na etapa inicial, ou seja, após a identificação das características das séries de preços realizou-se os teste de eficiência de mercado futuro propriamente. Essa compreendeu a especificação de um modelo utilizado para realizar o teste de eficiência do mercado futuro de açúcar da BM\&F, CSCE e LIFFE, para o hedger brasileiro. 


\subsubsection{Características das Séries de Preços}

A análise das características de estacionariedade das séries foi conduzida utilizando-se o teste de Dickey Fuller Aumentado (ADF) para investigar a significância estatística da hipótese nula de raiz unitária $I(I)$. Conforme indicado no Anexo, são três os modelos estimados, e os testes correspondentes a esses equivalem às estatísticas para determinar a forma do modelo mais adequada à série temporal, considerando-se: AR(1), estatística $\tau, \operatorname{AR}(1)$ com constante, estatística $\tau_{\mu} ; \mathrm{AR}(1)$ com constante e tendência, estatística $\tau_{\tau}$

Os resultados desses testes para raiz unitária são apresentados na Tabela 6 . Verifica-se, pelos resultados obtidos, que as quatro séries de preços apresentam apenas uma raiz unitária. Os baixos valores das estatísticas $\tau, \tau_{\mu}$, e $\tau_{\tau}$. apresentados para a estimativa das regressões com as variáveis em nível indicam a existência de pelo menos uma raiz unitária, dado que a hipótese nula não é rejeitada. Os valores estatisticamente significativos para as variáveis na primeira diferença confirmam que as séries são integradas de primeira ordem (possuem apenas uma raiz unitária) para os três modelos estimados, de forma que essas devem ser tomadas nas suas diferenças para que se tornem estacionárias.

As séries consideradas para a análise e suas respectivas representações são as seguintes:

(i) (S) - série de preços do Mercado Disponivel ou Spot do Açúcar;

(ii) $(F B)$ - série de preços do Mercado Futuro do Açúcar da BM\&F;

(iii) $\left(F C\right.$ - série de preço do Mercado Futuro do Açúcar da CSCE (contrato $n^{\circ} 11$ ); $\mathrm{e}$

(iv) $(F L)$ - série de preços do Mercado Futuro do Açúcar da LIFFE (contrato $\mathrm{n}^{\circ}$ 5).

As séries representadas pelos modelos incluindo constante, e, constante e tendência, não apresentaram parâmetros significativos, sendo que a estatística $\tau$ será a 
considerada para a identificação da presença de uma raiz unitária, $\mathrm{I}(1)$, em todas as séries analisadas, conforme mostra a Tabela 6 .

Tabela 6. Teste de raiz unitária: Média Semanal do Indicador de Preço de Açúcar Cristal ESALQ/BM\&F (S), Cotações do Mercado Futuro de Açúcar da BM\&F (FB), da CSCE (FC); e da LIFFE (FL). Período: 14/04/1997 a 28/04/2000.

\begin{tabular}{|c|c|c|c|}
\hline Variáveis & $\tau$ & $\tau_{\mu}$ & $\tau_{\tau}$ \\
\hline$S$ & -0.815 & -1.322 & -0.140 \\
\hline$F B$ & -0.236 & -1.050 & -0.002 \\
\hline$F C$ & -0.471 & -1.204 & 0.433 \\
\hline$F L$ & -0.776 & -1.318 & 0.515 \\
\hline$\Delta S$ & $-5.816^{*}$ & $-5.799^{*}$ & $-5.929^{*}$ \\
\hline$\Delta F B$ & $-9.499^{*}$ & $-9.468^{*}$ & $-9.538^{*}$ \\
\hline$\Delta F C$ & $-12.999^{*}$ & $-12.962^{*}$ & $-13.224^{*}$ \\
\hline$\Delta F L$ & $-12.843^{*}$ & $-12.828^{*}$ & $-13.074^{*}$ \\
\hline
\end{tabular}

* - significativo a 1\%, segundo estatística de Dickey-Fuller Aumentado.

Fonte: resultados da pesquisa.

Tendo-se determinado que as séries de preços no mercado físico e em cada um dos mercados de futuros são integradas de mesma ordem (1), ao nível de confiança de $99 \%$, passou-se a seguir, à estimativa das regressões de co-integração propostas no capitulo 4.

\subsubsection{Testes de Co-integração para Eficiência de Mercado}

Sabendo-se que as séries de preços no mercado fisico e em cada um dos mercados de futuros são integradas de mesma ordem, passou-se, a seguir, à realização do teste de co-integração entre os pares de séries formados sempre de acordo com o 
modelo especificado para o teste de eficiência dos mercados futuros. As variáveis são trabalhadas em nível, e o teste foi conduzido tomando-se a série de preços no mercado à vista $(S)$ como variável dependente e as séries dos preços futuros da BM\&F, CSCE e LIFFE como variáveis independentes com 6 defasagens, separadas em cada regressão de co-integração. Gujarati (1995) afirma que se as séries são integradas de mesma ordem, e os resíduos da regressão das séries no nível são estacionários, as variáveis podem ser cointegradas. Nesse caso, a regressão das séries no nível não é espúria, não perdendo-se assim alguma informação de longo-prazo, o que poderia ocorrer caso se utilizasse as séries nas diferenças. Esse autor afirma que os resíduos podem ser estacionários pelo fato de serem uma combinação linear das variáveis, sendo que as tendências das séries cancelam-se quando combinadas nesta forma.

O teste de co-integração utilizado foi o de Engle-Granger Aumentado (EGA) em dois estágios, baseado em estatísticas de Dickey Fuller Aumentado. Os resultados obtidos para a BM\&F são apresentados na Tabela 7. Pode-se destacar nessas regressões que os termos associados à variável $F_{\ell-j}$, (onde $j=1,2,3,4,5$, e 6 ), que indica o preço futuro defasado em até 6 semanas, está sempre próximo de um para o Mercado Futuro da BM\&F, sinalizando que esse Mercado Futuro reflete os preços Spot do açúcar do mercado disponível nacional. O teste $t$ para o termo constante indica que este não existe, ou seja, não é estatisticamente diferente de zero, para até quatro defasagens do preço futuro, o que mais uma vez condiz com a condição de mercado eficiente. Já para a quinta e sexta defasagens, os resultados indicam a presença de um prêmio constante de risco de longo-prazo, sendo que, nesse caso, pode-se inferir que a partir da quinta defasagem, o Mercado Futuro do Açúcar da BM\&F pode ser eficiente mesmo que seja viesado. 
Tabela 7. Regressões de Co-integração. Média semanal do Indicador de Preço de Açúcar Cristal ESALQ/BM\&F (S) e Cotações do Mercado Futuro de Açúcar da BM\&F (FB) Período: 14/04/1997 a 28/04/2000.

\begin{tabular}{|c|c|c|}
\hline Regressões & $R^{2}$ & $E G A^{\#}$ \\
\hline $\begin{array}{c}S_{0}=0.399399+0.983347 F B_{-I} \\
t=(1.30)^{* * *} \quad(33.22)^{*}\end{array}$ & 0.87 & $-9.498^{*}$ \\
\hline $\begin{array}{c}S_{0}=0.444478+0.977531 F B_{-2} \\
t=(1.44)^{* * *} \quad(32.78)^{*}\end{array}$ & 0.87 & $-3.595^{*}$ \\
\hline $\begin{array}{c}S_{0}=0.500081+0.971215 F B_{-3} \\
t=(1.58)^{* * *} \quad(31.63)^{*}\end{array}$ & 0.86 & $-3.252 *$ \\
\hline $\begin{array}{c}S_{0}=0.605496+0.959790 F B_{-4} \\
t=(1.80)^{* * *} \quad(29.47)^{*}\end{array}$ & 0.85 & $-2.880^{*}$ \\
\hline $\begin{array}{c}S_{0}=0.760232+0.943026 F B_{.5} \\
T=(2.09)^{* *} \quad(26.79)^{*}\end{array}$ & 0.82 & $-2.671^{*}$ \\
\hline $\begin{array}{c}S_{0}=0.948454+0.922937 F B_{-6} \\
T=(2.41)^{* *} \quad(26.79)^{*}\end{array}$ & 0.79 & $-2.523^{* *}$ \\
\hline
\end{tabular}

* - significativo a $1 \%$.

** - significativo a $5 \%$.

*** - não significativo.

\# - Engle-Granger Aumentado.

Fonte: resultados da pesquisa. 


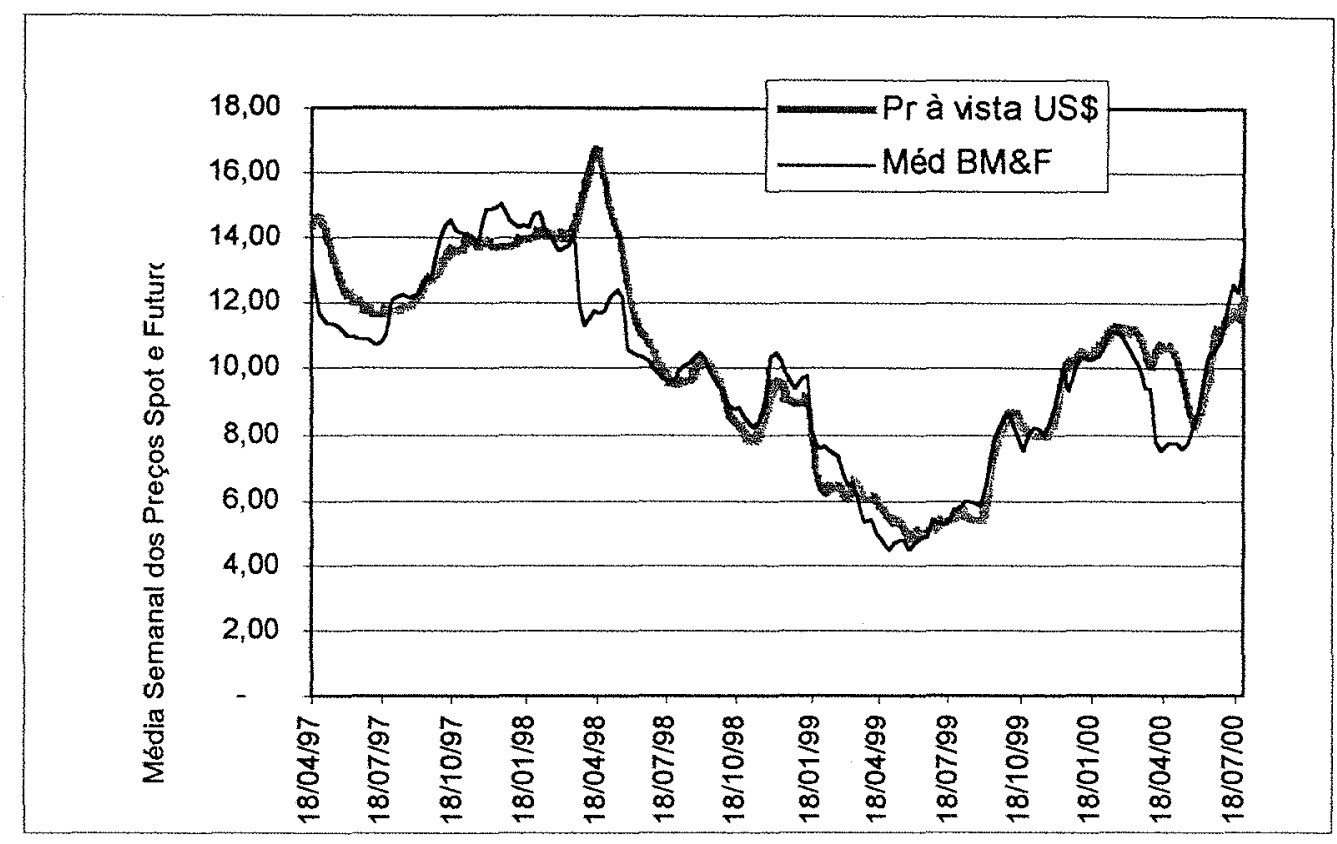

Figura 3. Comportamento dos Preços do Açúcar no Mercado Disponível Brasileiro e Mercado Futuro da BM\&F (1 ${ }^{\circ}$ vencimento). Médias Semanais. Período: 14/04/1997 à 28/07/2000.

A Figura 3 ilustra o comportamento do preço spot e o preço futuro do açúcar da BM\&F. Percebe-se através dessa que não existe descolamento significativo entre essas duas variáveis o que pode ser um indicador a mais para a consistência dos resultados alcançados através do teste de co-integração.

Contudo, conforme exposto no Capítulo 4, a existência da co-integração é condição necessária, porém não suficiente para a condição de Mercado Futuro Eficiente. Para que mercado futuro seja eficiente o coeficiente de co-integração tem que ser igual a um, o que equivale a testar a estacionariedade de $u_{t-j}=S_{t}-\delta F_{t-j}$, de forma a assegurar a eficiência de mercado e inexistência de viés, dentro de um contexto de longo-prazo, ou seja, não se rejeitando a hipótese de que $\alpha=0$ e $\delta=1$. Os resultados referentes a essa análise são apresentados na Tabela 8 . 
Tabela 8. Regressões de Co-integração. Estacionariedade dos resíduos. Média semanal do Indicador de Preço de Açúcar Cristal ESALQ/BM\&F (S) e Cotações do Mercado Futuro do Açúcar da BM\&F (FB) Período: 14/04/1997 a 28/04/2000.

\begin{tabular}{|c|c|}
\hline Regressões & $E G A^{\#}$ \\
\hline$u_{1}=S_{0}-\delta F B_{-1}$ & $-3.299^{*}$ \\
\hline$u_{2}=S_{0}-\delta F B_{-2}$ & $-3.658^{*}$ \\
\hline$u_{3}=S_{0}-\delta F B_{-3}$ & $-3.327^{*}$ \\
\hline$u_{4}=S_{0}-\delta F B_{-4}$ & $-2.974^{*}$ \\
\hline$u_{5}=S_{0}-\delta F B_{-5}$ & $-2.781^{*}$ \\
\hline$u_{6}=S_{0}-\delta F B_{-6}$ & $-2.647^{*}$ \\
\hline
\end{tabular}

* - significativo a $1 \%$.

\# - Engle-Granger Aumentado.

Fonte: resultados da pesquisa.

A verificação de que a variável $u_{t}$ é estacionária, a partir da aplicação do Teste de Engle Granger Aumentado, implica que $S_{t}$ e $F_{t-j}$ são co-integrados com parâmetro igual à unidade. Como pode ser observado na Tabela 8 , para todas as séries $u_{t-j}$, a hipótese nula de não estacionariedade foi rejeitada. Isso indica que, para as seis semanas anteriores à semana do preço spot, o Mercado Futuro do Açúcar da BM\&F se mostra eficiente. Isso porque os preços futuros refletem todas as informações disponíveis relevantes, para até quatro defasagens, o que permite afirmar que, para esse período os preços futuros são estimadores não viesados dos preços à vista. Contudo, conforme pode se verificar através das Tabelas 7 e 8 , os valores dos testes e dos parâmetros permitem afirmar ainda que os preços futuros do açúcar da BM\&F, com maior defasagem, num contexto de longo-prazo, são estimadores viesados do preço do açúcar no mercado disponível ainda que sejam eficientes. Isso ocorre devido ao acúmulo de informações por parte dos agentes ao se aproximar a data do fechamento do contrato. É valido ressaltar que, conforme discutido no Capítulo 4, o conceito de Eficiência de Mercado diz respeito ao fato de que os preços futuros, em tempo corrente, devem igualar-se aos preços esperados do mercado spot para periodos futuros, devendo-se somar ou subtrair a esses um possível prêmio de risco. 
Para medir a eficiência do Mercado Futuro do Açúcar da CSCE para hedgers nacionais, empregou-se o mesmo procedimento anterior. Os resultados dessa análise são apresentados na Tabela 9. O melhor nível de significância do Teste EGA para os resíduos da regressão de co-integração foi $10 \%$. Além disso, foi detectada a significância estatística da constante para cada modelo como sendo igual a $1 \%$, o que permite dizer que o Mercado Futuro do Açúcar da CSCE sujeita o hedger nacional a um prêmio constante pelo risco, ainda que exista co-integração para as variáveis até a terceira defasagem, ao nível de $90 \%$ de confiança. A partir da quarta semana de defasagem o preço futuro do açúcar da CSCE não se apresenta co-integrado ao preço spot do açúcar no mercado disponivel nacional, o que pode ser verificado pela não significância estatística do teste EGA para as quarta, quinta e sexta defasagens.

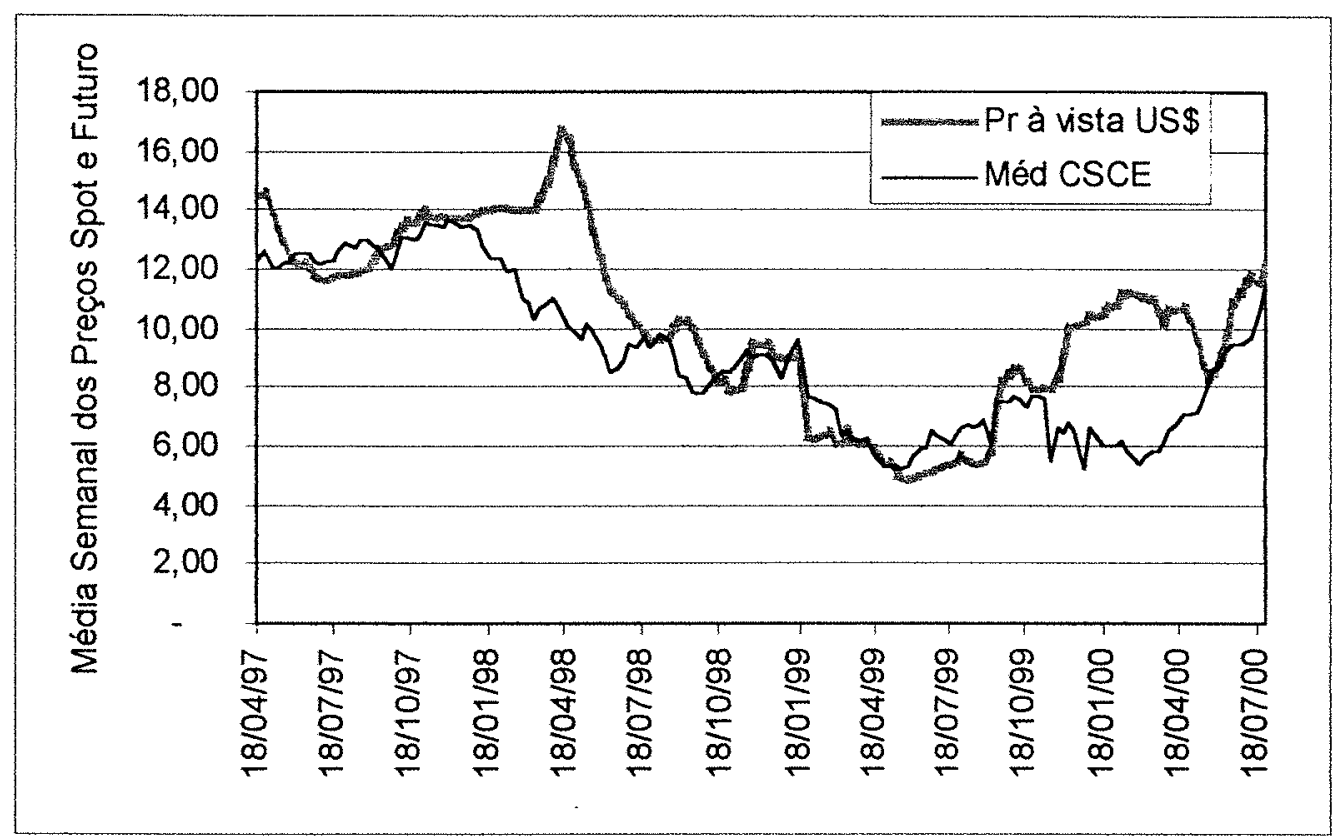

Figura 4. Comportamento dos Preços do Açúcar no Mercado Disponível Brasileiro e Mercado Futuro da CSCE ( $1^{\circ}$ vencimento). Médias Semanais. Periodo: 14/04/1997 à 28/07/2000. 
O comportamento relativamente adverso das variáveis preço spot do açúcar no mercado disponível doméstico e preço futuro do açúcar na CSCE pode ser ilustrada através da Figura 4.

Para testar a hipótese de que o mercado futuro do açúcar da CSCE é relativamente eficiente para, pelo menos até a terceira semana defasada, o coeficiente de co-integração, conforme dito anteriormente, de $u_{t-j}=S_{\mathrm{t}}-\delta F_{t-j}$ tem que ser igual a um, o que equivale a testar a estacionariedade de $u_{t-j}$.

Tabela 9. Regressões de Co-integração. Média Semanal do Indicador de Preço de Açúcar Cristal ESALQ/BM\&F $(S)$ e Cotações do Mercado Futuro de Açúcar da CSCE (FC). Período: 14/04/1997 a 28/04/2000.

\begin{tabular}{|c|c|c|}
\hline Regressões & $R^{2}$ & $E G A^{\#}$ \\
\hline $\begin{array}{c}S_{0}=2.278478+0.872463 F C_{-1} \\
t=(4.20)^{*} \quad(15.15)^{*}\end{array}$ & 0.59 & $-1.812^{* * *}$ \\
\hline $\begin{array}{c}S_{0}=2.321926+0.865588 F C_{-2} \\
t=(4.28)^{*} \quad(15.02)^{*}\end{array}$ & 0.59 & $-1.746^{* * *}$ \\
\hline$S_{0}=2.349481+0.860410 F C_{-3}$ & & \\
$t=(4.32)^{*} \quad(14.92)^{*}$ & 0.58 & $-1.680^{* * *}$ \\
\hline$S_{0}=2.368138+0.856400 F C_{-4}$ & & \\
$t=(4.36)^{*} \quad(14.84)^{*}$ & 0.58 & $-1.759 * * *$ \\
\hline$S_{0}=2.397223+0.851522 F C_{-5}$ & & \\
$t=(4.39)^{*} \quad(14.68)^{*}$ & 0.58 & $-1.563 * * * *$ \\
\hline$S_{0}=2.435109+0.845956 F C_{-6}$ & & $-1.574^{* * * *}$ \\
\hline
\end{tabular}

* - significativo a $1 \%$.

$* *$ - significativo a $5 \%$.

$* * *$ - significativo a $10 \%$.

**** - não significativo.

\# - Engle-Granger Aumentado.

Fonte: resultados da pesquisa. 
Como pode ser observado na Tabela 10 , para as séries $u_{t-j}$ até a terceira defasagem a hipótese nula de não estacionariedade foi rejeitada a $10 \%$ de significância estatístitica. Portanto, para as três semanas anteriores à semana do preço spot o Mercado Futuro do Açúcar da CSCE mostra-se eficiente, num conceito de longo-prazo, a $90 \%$ de confiança, porém viesado, pois sinaliza a existência de um prêmio de risco de longoprazo constante.

Tabela 10. Regressões de Co-integração. Estacionariedade dos resíduos. Média semanal do Indicador de Preço de Açúcar Cristal ESALQ/BM\&F (S) e Cotações do Mercado Futuro do Açúcar da CSCE (FC) Período: 14/04/1997 a 28/04/2000.

\begin{tabular}{|c|c|}
\hline Regressões & $E G A^{\#}$ \\
\hline$u_{1}=S_{0}-\delta F C_{-1}$ & $-1.887^{* * *}$ \\
\hline$u_{2}=S_{0}-\delta F C_{-2}$ & $-1.864^{* * *}$ \\
\hline$u_{3}=S_{0}-\delta F C_{-3}$ & $-1.818^{* * *}$ \\
\hline
\end{tabular}

*** - significativo a $10 \%$.

\# - Engle-Granger Aumentado.

Fonte: resultados da pesquisa.

O procedimento utilizado para medir a eficiência do Mercado Futuro do Açúcar da LIFFE para hedgers nacionais seguiu o mesmo raciocínio das investigações anteriores. Os resultados para essa análise são apresentados na Tabela 11. Como pode ser verificado, não há evidência estatística de que esse mercado seja eficiente para os hedgers nacionais. Posto de outro forma, não se pode dizer, estatisticamente, que os preços futuros do açúcar da LIFFE são estimadores eficientes e não viesados do preço spot do açúcar no mercado disponível brasileiro, uma vez que o teste EGA mostrou-se não significativo para todas as regressões de co-integração. 
Tabela 11. Regressões de Co-integração. Média Semanal do Indicador de Preço de Açúcar Cristal ESALQ/BM\&F (S) e Cotações do Mercado Futuro de Açúcar da LIFFE $(F L)$. Período: $14 / 04 / 1997$ a 28/04/2000.

\begin{tabular}{|c|c|c|}
\hline Regressões & $R^{2}$ & $E G A^{\#}$ \\
\hline $\begin{aligned} S_{0} & =0.910681+0.776694 F L_{-1} \\
t & =(1.50)^{* * * *} \quad(11.98)^{*}\end{aligned}$ & 0.47 & $-1.339 * * * *$ \\
\hline $\begin{array}{c}S_{0}=1.071623+0.865588 F L_{-2} \\
t=(1.34)^{*}(11.65)^{*}\end{array}$ & 0.46 & $-1.307 * * * *$ \\
\hline $\begin{array}{c}S_{0}=1.200894+0.748434 F L_{-3} \\
t=(1.49)^{* * * *} \quad(11.36)^{*}\end{array}$ & 0.45 & $-1.269 * * * *$ \\
\hline $\begin{array}{c}S_{0}=1.305161+0.738037 F L_{-4} \\
t=(1.61)^{* * * *} \quad(11.12)^{*}\end{array}$ & 0.44 & $-1.138 * * * *$ \\
\hline $\begin{array}{c}S_{0}=1.405922+0.728097 F L_{-5} \\
t=(1.72)^{* *} \quad(10.87)^{*}\end{array}$ & 0.43 & $-1.122 * * * *$ \\
\hline $\begin{array}{cc}S_{0}=1.505822+ & 0.718482 F L_{-6} \\
t=(1.82)^{* *} & (10.62)^{*}\end{array}$ & 0.42 & $-1.152 * * * *$ \\
\hline
\end{tabular}

* - significativo a $1 \%$.

** - significativo a $5 \%$.

*** - significativo a $10 \%$.

**** - não significativo.

" - Engle-Granger Aumentado.

Fonte: resultados da pesquisa.

A Figura 5 ilustra o comportamento dessas variáveis, de modo que pode-se visualizar que as variáveis em questão apresentam comportamento relativamente adverso. 


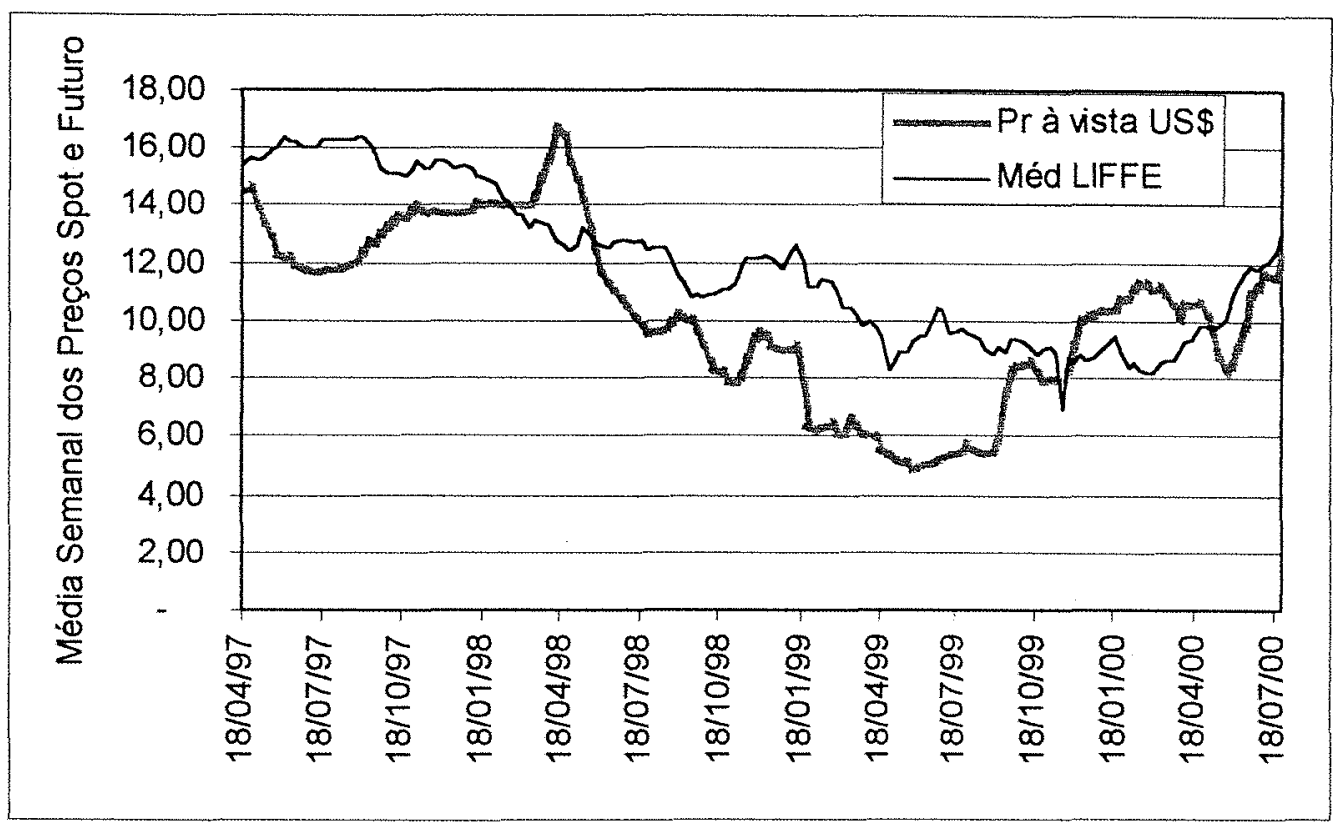

Figura 5. Comportamento dos Preços do Açúcar no Mercado Disponível Brasileiro e Mercado Futuro da LIFFE ( $1^{\circ}$ vencimento). Médias Semanais. Período: 14/04/1997 à 28/07/2000.

Portanto, de acordo com os resultados apresentados nessa sessão foi verificar, utilizando o conceito de Eficiência de Mercado e previsões não viesadas de preços spot, que o Mercado Futuro da BM\&F é mais apropriado para o hedger nacional, segundo esses conceito de Eficiência de longo-prazo.

\subsection{Estimativa da Eficiência de Hedge na BM\&F, CSCE e na LIFFE}

A análise empírica relativa à eficiência de hedge dos mercados futuros foi desenvolvida tomando-se como base os resultados obtidos na etapa inicial. Essa fase compreendeu a especificação de um modelo utilizado para realizar o teste de eficiência de hedge dos mercados futuros do açúcar da BM\&F, CSCE e LIFFE, para o hedger brasileiro. 
As regressões foram estimadas tendo como variável dependente a série de prę̧os do açúcar no mercado disponível (tomada na primeira diferença) e, como variáveis independentes, as séries de preços futuros do açúcar nas Bolsas em estudo, também tomadas na primeira diferença.

A Tabela 12 ilustra os resultados obtidos das regressões propostas. As regressões existem, para as variáveis em questão, a um nível de confiança de $99 \%$ (Teste $F$ ). Como o $R^{2}$ dessas regressões representa uma medida de redução do risco, através da comparação da variância do retorno de uma posição não hedgeada com a variância do retorno da posição a qual se utilizou hedge, nota-se a partir dos resultados que o mercado futuro mais eficiente para redução do risco do hedger brasileiro é o mercado futuro da BM\&F. O mercado futuro do açúcar da BM\&F reduz a exposição ao risco de variação inesperada de preço em cerca de $20 \%$, enquanto as Bolsas CSCE e LIFFE o fazem em $7,98 \%$ e $2,27 \%$ respectivamente.

Tabela 12. Estimativa do Modelo de Eficiência de Hedge do Mercado Futuro do Açúcar nas Bolsas BM\&F, CSCE E LIFFE. Período analisado: 14/04/1997 à 28/07/2000.

\begin{tabular}{|c|c|c|c|c|}
\hline $\begin{array}{c}\text { Variável } \\
\text { Dependente }\end{array}$ & $\begin{array}{c}\text { Variável } \\
\text { Independente }\end{array}$ & Teste $F$ & $\begin{array}{c}\text { Número de } \\
\text { Observações }\end{array}$ & $R^{2}$ \\
\hline$\Delta S$ & $\Delta F B$ & $39,92^{*}$ & 162 & 0,1997 \\
\hline$\Delta S$ & $\Delta F C$ & $13,89^{*}$ & 162 & 0,0798 \\
\hline$\Delta S$ & $\Delta F L$ & $4,74^{*}$ & 162 & 0,0227 \\
\hline
\end{tabular}

* Significativo a $1 \%$

Fonte: resultado da pesquisa.

\subsection{Cross Hedge e Risco Residual Relativo - Resultados}

Essa etapa é um refinamento dos resultados obtidos no tópico anterior, de forma que se constitui em uma ferramenta importante para análise de proteção contra risco de variação de preço para o hedger. Os resultados alcançados pela avaliação da eficiência de operações de cross hedges através do cálculo do risco residual relativo, conforme 
procedimento apresentado no item (4.3), baseado em Black (1986), são apresentados e discutidos em etapas.

O primeiro fator analisado correspondeu à verificação da existência de ganhos potenciais efetivos com a introdução ou utilização dos contratos futuros de açúcar da BM\&F, vis a vis contratos futuros que podem ser considerados como substitutos próximos no sentido de possibilitar a realização da operação de hedge do açúcar e proporcionar um cross hedge eficiente.

A abordagem do cross hedge eficiente estabelece que outros contratos futuros já atendem de forma adequada os hedgers de uma commodity (em termos de redução de risco e com baixo custo de liquidez). Dessa forma, a introdução de uma alternativa ou inovação, no sentido de reduzir o risco para o hedger que venha a utilizar, a princípio, os contratos futuros de açúcar na BM\&F, mediante a composição de portfolios com contratos de açúcar de bolsas de futuros no mercado internacional, pode não contribuir para reduzir o risco residual, diminuindo o interesse pela sua utilização. Considera-se, para tal, que o contexto analítico pressupõe que os custos de operação são semelhantes, a despeito do local em que a operação é realizada.

O objetivo dessa análise, conforme apresentado anteriormente, consiste em identificar se o cross hedge pode ser considerado como fator de fracasso ou desestímulo à utilização mais intensiva do mercado doméstico, para a realização do hedge direto.

As expectativas são de que valores relativamente altos para as proporções de redução de risco, calculadas através do $R^{2}$, podem sugerir que as alternativas existentes não têm-se constituído em fatores impeditivos para que os produtores e/ou detentores de açúcar doméstico, ceteris paribus, utilizem a BM\&F para a realização de operações de hedge com o açúcar.

Os resultados das regressões entre as variáveis em termos de seu coeficiente de determinação, analisando os casos de portfolios compostos para own hedging $\left(R_{o}^{2}\right) \mathrm{e}$ cross hedging $\left(R_{c}^{2}\right)$, são os apresentados na Tabela 12 , sendo que a razão entre essas 
variáveis é utilizada para expressar o valor do risco residual relativo, conforme descrito no item (4.3).

$\mathrm{O}$ risco residual, que pode ser calculado tomando-se $\left(1-R^{2}\right)$, expressa a proporção do risco do portfolio hedgeado que permanece após a realização de uma operação de hedge. Ou seja, no caso da realização de operações de hedge na BM\&F, cerca de $80 \%$ do risco permanece após a realização do hedge, tendo-se considerado para a estimativa das regressões séries de médias semanais que englobam o período abril de 1997 a julho de 2000.

Esse percentual de permanência do risco após a tomada de posição em mercados futuros apresenta-se bem mais elevado no caso dos resultados relativos à realização cross hedge na CSCE e na LIFFE, $92 \%$ e $98 \%$ respectivamente, sugerindo que a realização de cross hedge pelo produtor nacional não se constitui, a princípio, em fator impeditivo do sucesso do mercado futuro de açúcar na BM\&F durante o período tomado para a análise.

Considerando-se o conceito de risco residual relativo, conforme definido por Black (1986), tem-se que os resultados apresentados na Tabela 13 sugerem que a preferência do hedger de açúcar seria pelo hedge direto na BM\&F, sendo que ambos os valores estimados dessa variável apresentam-se relativamente altos.

Através da última coluna da Tabela 13 pode se observar que os valores da variável risco residual relativo são superiores à unidade. Isso indica que o cross hedge submete o hedger a muito mais risco do que o own hedge. Os resultados encontrados mostram que se o hedger brasileiro assumir posição na $\mathrm{CSCE}$, estará aproximadamente 1,15 vezes mais exposto ao risco do que se realizar o hedge na BM\&F. Da mesma forma, se o hedge for realizado na LIFFE, a exposição ao risco será cerca de 1,22 maior do que se fosse realizado o own hedge.

Esses resultados são condizentes com os obtidos nas outras análises feitas anteriormente nesse trabalho, ou seja, nos três conceitos utilizados para verificar a performance do Contrato Futuro Cambial do Açúcar da BM\&F, Eficiência de Mercado, 
Eficiência de hedge e Risco Residual Relativo, esse mercado futuro se mostrou mais eficiente para hedger nacional do que os mercados alternativos internacionais aqui analisados.

Tabela 13. Estimativas da Variável Risco Residual Relativo $\left(R R_{i}\right)$ considerando Relações de Operações de hedge direto (BM\&F) e cross hedges (CSCE ou LIFFE). Período: 14/04/1997 a 28/07/2000.

\begin{tabular}{|c|c|c|c|c|c|}
\hline $\begin{array}{c}\text { Mercado } \\
\text { Disponível } \\
\text { (Local) }\end{array}$ & $\begin{array}{c}\text { Mercado } \\
\text { Futuro } \\
\text { (Bolsa) }\end{array}$ & $\begin{array}{c}\text { Mercado } \\
\text { Cross Hedge } \\
\text { (Bolsa) }\end{array}$ & $\begin{array}{c}\text { Risco } \\
\text { Residual } \\
\text { Cross Hedge } \\
R_{c}\end{array}$ & $\begin{array}{c}\text { Risco } \\
\text { Residual } \\
\text { Own Hedge } \\
R R_{o}\end{array}$ & $\begin{array}{c}\text { Risco } \\
\text { Residual } \\
\text { Relativo } \\
\quad R R_{i}\end{array}$ \\
\hline Brasil & $\mathrm{BM} \& \mathrm{~F}$ & CSCE & 0,9202 & 0,8003 & 1,1498 \\
\hline Brasil & BM\&F & LIFFE & 0,9773 & 0,8003 & 1,2212 \\
\hline
\end{tabular}

Fonte: resultado da pesquisa.

\subsection{Taxa de Juros, Taxa Própria e o Volume de Negociação do Contrato Futuro Cambial do Açúcar na BM\&F}

A análise da correlação entre o volume de negociação do Contrato Futuro Cambial e o diferencial entre a taxa de juros de mercado e a taxa de remuneração do açúcar no mercado futuro foi realizada tomando-se estas variáveis em suas médias semanais. Os dados relativos às variáveis do Mercado Futuro referem-se aos contratos do primeiro vencimento em aberto.

Essa abordagem teve como objetivo verificar a correlação entre o diferencial entre a taxa própria da commodity em questão e a taxa de juros e o volume de contratos do açúcar negociados na BM\&F, de forma que tal análise se constitui em um dos objetivos dessa pesquisa, ou seja, mensurar a correlação de um indicador construído com 
essa variável macroeconômica (taxa de juros), via diferencial, e o grau de associação com a variável microeconômica (Volume de negócios do Contrato do açúcar na BM\&F).

A variável taxa de remuneração do açúcar na BM\&F foi construída utilizando-se as séries de preços do açúcar no mercado disponível (à vista) e no mercado futuro da bolsa, sendo posteriormente confrontada com a taxa de juros de mercado, conforme ilustra a Figura 6. Através da fórmula (12) apresentada no capítulo 4, pode-se notar que quanto maior for o preço futuro, para dado preço à vista, considerando-se também o fator tempo, maior será a taxa de remuneração no mercado futuro.

A Tabela 14 indica o valor do coeficiente de correlação encontrado, mostrando que existe uma associação positiva entre o Volume de Contratos em Aberto (negociados) e o diferencial entre a taxa própria e a taxa de juros. Isso, por sua vez, sinaliza que quanto maior for a taxa de remuneração da commodity açúcar no Mercado Futuro da BM\&F, descontada a taxa de juros, maior vai ser o Volume de Contratos em Aberto.

Tabela 14. Estimativa da Correlação entre o Volume de Contratos em Aberto $(V)$ e o Diferencial $(d)$ entre a Taxa Própria do Açúcar e a Taxa de Juros. Período: 14/04/1997 à 28/07/2000.

\begin{tabular}{c|c}
\hline Variáveis & $\rho$ \\
\hline$V$ e $d$ & 0,201906 \\
\hline
\end{tabular}

Fonte: resultados da Pesquisa. 


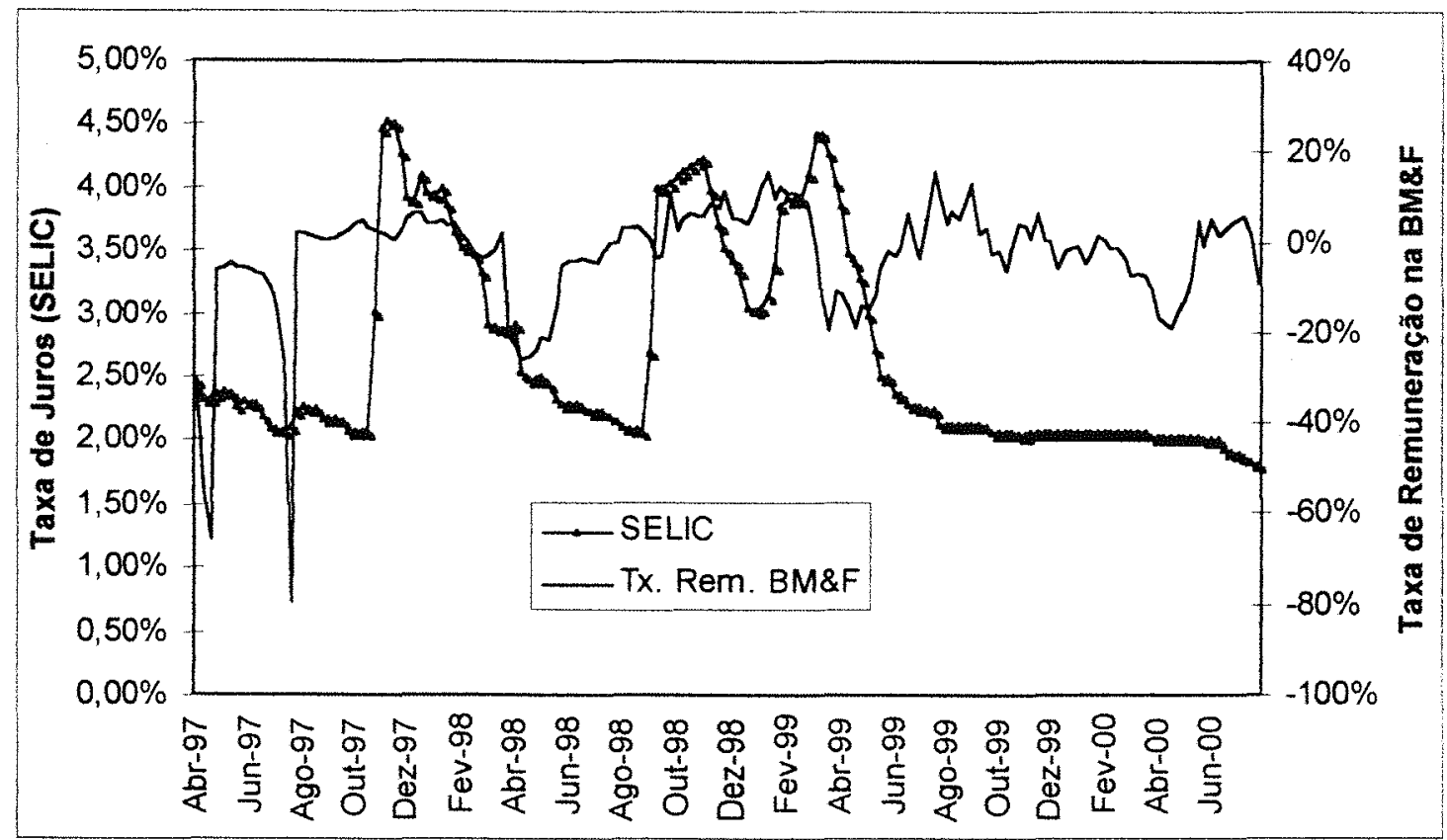

Figura 6. Taxa de Juros de Mercado e a Taxa de Remuneração do Açúcar Brasileiro na BM\&F. Período: 14/04/1997 à 28/07/2000.

A estatística $t$ utilizada para verificar a existência do coeficiente de correlação $\rho$ indicou, conforme procedimento proposto no capítulo 4, que o grau de associação linear entre $V$ e $d$ existe ao nível de significância de $1 \%$. Sendo que o valor do $t_{c a l}$ (calculado) foi 2,591 e o valor do $t$ tabelado, a $1 \%$ de siginificância, 2,576.

No aspecto prático, a percepção de uma considerável remuneração do açúcar no mercado futuro que cubra os custos de oportunidade do dinheiro pode fazer com que o detentor da commodity armazene-a e venda contratos futuros, na BM\&F.

É importante ressaltar que a inferência feita não faz menção à análise de causalidade entre as duas variáveis $(V$ e $d)$, somente à intensidade do grau de associação linear existente entre elas, sendo que também não significa que não exista alguma outra forma (não linear) de associação entre essas, com intensidade diferente. 


\section{CONCLUSÕES}

Esta pesquisa realizou uma investigação voltada à identificação e análise de fatores que podem ter-se constituído em restrições à utilização mais intensa do contrato de futuros de açúcar da Bolsa de Mercadorias e Futuros (BM\&F), com relação à que vem sendo observada desde o seu lançamento. A pesquisa foi conduzida empregando-se um conjunto de procedimentos para a realização de análises quantitativas, tanto no contexto microeconômico quanto no âmbito macroeconômico. Foram empregados quatro procedimentos, selecionados junto à literatura relacionada, por se apresentarem adequados ao propósito da presente pesquisa.

Uma das ferramentas utilizadas para avaliar o desempenho do Contrato Futuro Cambial do Açúcar da BM\&F foi a análise de eficiência de mercados futuros. Através dessa abordagem foram obtidas indicações de que o Contrato Futuro Cambial do Açúcar da BM\&F mostrou-se, para o período analisado, mais eficiente do que os mercados futuros do açúcar da London International Financial and Futures Exchange (LIFFE) e da Cocoa, Sugar and Coffee Exchange (CSCE). Essa eficiência diz respeito à capacidade do Mercado Futuro do Açúcar da BM\&F em fornecer previsões eficientes dos preços à vista e também não viesadas, para um hedger nacional, considerando-se um contexto de longo prazo. Já o Mercado Futuro do Açúcar da CSCE apresentou-se eficiente até a terceira defasagem ( 3 semanas), expondo, no entanto, o hedger nacional a um prêmio de risco de longo prazo, enquanto que o Mercado Futuro do Açúcar da LIFFE foi considerado ineficiente.

A segunda abordagem utilizou o conceito de Eficiência de Hedge. Através desta análise foi possível verificar que o Mercado Futuro do Açúcar da BM\&F reduz em 
maior proporção a exposição ao risco de variação inesperada de preço da commodity açúcar no mercado disponível local, quando comparada à de outros contratos futuros de expressão internacional contemplados nessa pesquisa.

A avaliação da variável risco residual relativo foi a terceira abordagem empregada. Nesse conceito foi possível mensurar em quanto varia a exposição ao risco do hedger nacional que assume posição em futuros de açúcar nas bolsas CSCE e LIFFE ao invés de fazê-lo na BM\&F. Condizente com as análises anteriores, essa averiguação sugere que, ao assumir uma posição em futuros nas bolsas internacionais consideradas, o hedger brasileiro aumenta significativamente a sua exposição ao risco.

Finalmente, além desses aspectos, que se identificam com um contexto analítico de natureza essencialmente microeconômica, realizou-se uma análise de como variáveis de natureza macroeconômica também influenciam o sucesso do Contrato de Futuros. Mais especificamente, verificou-se a forma pela qual a variação da taxa de juros pode ter influenciado o volume de negócios do Contrato Futuro Cambial do Açúcar da BM\&F, ao longo do período englobado pela análise.

Os resultados obtidos através dessas análises complementares indicaram que, de uma maneira geral, o Contrato Futuro Cambial de Açúcar da BM\&F atende aos requisitos avaliados. Além disso, os parâmetros de desempenho apresentaram-se relativamente mais favoráveis a esse contrato, sob o enfoque de adequação às necessidades de um hedger brasileiro, quando comparados aos de seus potenciais substitutos no âmbito internacional. Uma conclusão importante, que se deriva desses resultados, é que o Contrato Futuro de Açúcar brasileiro tem potencial relevante a ser explorado pelos agentes que comercializam açúcar no mercado nacional, de forma que a divulgação de informações e a promoção de treinamento para a utilização adequada desse instrumento destacam-se como fatores importantes que podem intensificar sua utilização.

Deve-se considerar ainda, que a reorganização do setor sucroalcooleiro em decorrência da exposição dos agentes de mercado, a todos os níveis, a condições mais próximas de mercado competitivo deve promover uma busca de eficiência. Se o 
mercado futuro proporciona potencial para desempenhar adequadamente suas atribuições, espera-se que esse venha a ser progressivamente utilizado à medida que o setor passa a investir no desenvolvimento de capital humano com nível mais elevado de capacitação para entender e utilizar instrumentos mercadológicos mais elaborados.

Inferências a partir dos resultados obtidos com a análise de eficiência de mercado devem considerar que uma das principais finalidades dos mercados futuros de commodities agrícolas é a de servir como instrumento de administração de risco para negociações envolvendo risco de preços no mercado à vista. O sucesso de um contrato futuro específico está condicionado, portanto, dentre outros objetivos, à habilidade de um hedger potencial em antecipar, de forma acurada, a relação futura entre os preços do mercado à vista e no mercado futuro.

Um outro aspecto importante refere-se ao consumidor industrial, o qual compra grandes volumes para utilização do açúcar como matéria prima junto com outros insumos para a obtenção de seu produto final. A princípio, isso faria com que o mercado futuro não fosse um instrumento para esse agente também, dado que a participação do açúcar na composição de seu produto é relativamente marginal.

Contudo, sugere-se, como extensão dessa pesquisa, a verificação de como o mercado futuro do açúcar pode desempenhar suas funções para as diferentes classes de consumidores, finais e intermediários, de modo a identificar e quantificar os benefícios dessas funções. Nessa mesma linha, esse tipo de averiguação pode ainda ser extrapolado para análises de sensibilidade na apuração de custos e relações de preços que possam contribuir para uma avaliação quantitativa da viabilidade econômico financeira desse setor, ou setores correlacionados, podendo tornar-se um estímulo à intensificação da utilização desse instrumento de gerenciamento de risco de variação inesperada de preço. 


\section{REFERÊNCIAS BIBLIOGRÁFICAS}

ANDERSON, R.W. ; DANTHINE, J.P. Cross hedging. Journal of Political Economy, v.89, n.6, p.1182-1196, 1981.

ARBEX, M.A. ; CARVALHO, V.D. Eficiência no mercado futuro de café brasileiro, no período de 1992 a 1998. Revista Brasileira de Economia e Sociologia Rural, v.37, n.1, p. 97-113, 1999.

BAER, Werner. A economia brasileira. São Paulo: Nobel, 1996. 416p.

BARNHART, S.W. ; KAHL, H.K. ; BARNHART, C.M. An empirical analysis of the alleged manipulation attempt and forced liquidation of the July 1989 soybean futures contract. The Journal of Futures Markets, v.16, n.7, p.781-808, 1996.

BECK, S. Cointegration and market efficiency in commodities futures markets. Applied Economics, v.26, p.249-257, 1994.

BLACK, D. Success and failure of futures contracts: theory an empirical evidence. New York, 1986-1. 70p. (Monograph Series in Finance and Economics)

BANCO CENTRAL DO BRASIL. Boletim do Banco Central do Brasil. Brasilia. (vários volumes)

BOND, Gary E. The effects of supply and interest rate shocks in commodity futures markets. American Journal of Agricultural Economics, v.66, n.3, p.294-301, 1984. 
BOND, G.E. ; THOMPSON, S.R. Offshore commodity hedging under floating exchange rates. American Journal of Agricultural Economics, v.69, n.1, p.46-55, 1987.

CARTER, C.A. Commodity futures market: a survey. The Australian Journal of Agricutural and Resource Economics, v.43, n.2. p.209-247, 1999.

FRANKEL, J.A. Commodity prices and money: lessons from international finance. American Journal of Agricultural Economics, v.66, p.560-66, 1984.

FRANKEL, J.A. Expectations and commodity price dynamics: the overshooting model. American Journal of Agricultural Economics, v.68, p.344-48, 1986.

FRANKEL, J.A. ; HARDOUVELIS, G.A. Commodity prices, money surprises and fed credibility. Journal of Money, Credit and Banking, v.17, n.4, part I, p.427-38, 1985.

FULLER, W.A. Introduction to statistical time series. New York: Wiley, 1976.

GILBERT, G.L. Futures trading and the welfare evaluation of commodity price stabilisation. The Economic Journal, n.95, p.637-661, Sep.1985.

GUJARATI, D.N. Basic econometrics. New York: McGraw-Hill, 1995. 838p.

HOEL, P.G.. Introduction to mathematical statistics. 4.ed. New York: John Wiley \& Sons, 1971. 409p.

JUNGMANN, Fernando. O direito da agro-indústria açucareira. São Paulo: Editora Revista dos Tribunais Ltda, 1971. 479p.

JUROS \& Moedas : banco de dados financeiros. São Paulo: Dinheiro Vivo Agência de Informações S/A. (vários números) 
KALDOR, N. Speculation and economic stability. Review of Economic Studies, v.7, p.1-27, 1939.

KAHL, K.H. Determination of the recommended hedging ratio. American Journal of Agricultural Economics, v.65, n.3, p.603-605, 1983.

KEYNES, J.M. A treatise on money. New York: Harcourt, Brace and Company, 1930. v.2. $424 \mathrm{p}$.

LARSON, D.F. ; VARANGIS, P. ; YABUKI, N. Commodity risk management and development. Washington: The World Bank, 1998. 35p. (Development Research Group)

LENCE, S.H. ; HAYENGA, M.L. ; PATTERSON, M.D. Storage profitability and hedge ratio estimation. The Journal of Futures Markets, v.16, n.6, p.655-676, 1996.

LEUTHOLD, R.M. ; JUNKUNS, J.C. ; CORDIER, J.E.. The theory and practice of futures markets. Lexington: Lexington Books, 1989. 410p.

LOZARDO, E. Derivativos no Brasil: fundamentos e práticas. São Paulo: Bolsa de Mercadorias \& Futuros, 1998. 254p.

MACKENZIE, A.M. ; HOLT, M.T. Market efficiency in agricultural futures markets / Presented in American Agricultural Economics Association Meeting in Salt Lake City, 1998.

MATTOS, F.L. Utilização de contratos futuros agropecuários em carteiras de investimentos: uma análise de viabilidade. Piracicaba, 2000. 104p. Dissertação (Mestrado) -- Escola Superior de Agricultura "Luiz de Queiroz", Universidade de São Paulo.

MOALLA-FETTINI, Rakia. Storage arbitrage condition and overshooting: an impossibility theorem. Berkeley: University of California. Dept. of Agriculture \& 
Resource Economics, 1990. 152p.

MOOSA, I.A. ; AL-LOUGHANI, N. The effectiveness of arbitrage and speculation in the crude oil futures market. The Journal of Futures Markets, v.15, n.2, p.167-186, 1995.

MORAES, M.A.F.D. A desregulamentação do setor sucroalcooleiro brasileiro. Piracicaba, 1999. 292p. Tese (Doutorado) -- Escola Superior de Agricultura "Luiz de Queiroz", Universidade de São Paulo.

PALASKAS, T. ; VARANGIS, P. Primary commodity prices and macroeconomic variables: a long run relationship. Washington: The World Bank, 1989. (Policy Research Working Paper, n.314)

PECK, A.E. Hedging and income stability: concepts, implications, and an example. American Journal of Agricultural Economics, v.57, n.1. p.410-419, 1975.

PINA, Hélio. A agro-indústria açucareira e sua legislação. São Paulo: Apec, 1972. $364 \mathrm{p}$.

PRADO Jr., Caio. História econômica do Brasil. São Paulo: Brasiliense, 1971. 354p.

RAO, B.B. Cointegration for the applied economist. New York: St. Martin's Press, 1994. 231p.

SATYANARAYAN, S. ; VARANGIS, P. An efficient frontier for international portfolios with commoity assets. Washington: The World Bank, 1994. 30p. (Policy Research Working Paper, n.1266)

SCHOUCHANA, Félix. Introdução aos mercados futuros e de opções agropecuários. São Paulo: Bolsa de Mercadorias \& Futuros, 1997. 70p.

SIMON, P.H. Estrutura agraria brasileña: período colonial. Florianópolis: UDESC/EPAGRI, 1997. 234p. 
SOUZA, W.A. Determinantes da viabilidade de mercados futuros agropecuários no âmbito do Mercosul. Piracicaba, 1999. 136p. Tese (Doutorado) -- Escola Superior de Agricultura "Luiz de Queiroz", Universidade de São Paulo.

SUSMEL, R. ; THOMPSON, A. Volatility, storage and convenience: evidence from natural gas markets. The Journal of Futures Markets, v.17, n.1, p.17-43, 1997.

TELSER, L.G. ; HIGINBOTHAM, H.N. Organized futures markets: costs and benefits. Jounal of Political Economy, v.85, n.5, p.969-1000, 1977.

THOMPSON, S. ; GARCIA, P. ; WILDMAN, L.D. The demise of the high fructose corn syrup futures contract: a case study. The Journal of Futures Markets, v.16, n.6, p.697-724, 1996.

TOMEK, W.G. ; PETERSON, H.H. Risk management in agricultural markets: a survey. In: Producer marketing and risk management: frontiers for the $21^{\text {st }}$ century. Orlando, Jan.2000.

TSETSEKOS, G. ; VARANGIS, P. The structure of derivatives exchange: lessons from developed and emerging markets. Washington: The World Bank, 1997. 28p. (Development Research Group)

VARANGIS, P. ; LARSON, D. Dealing with commodity price uncertainty. Washington: The World Bank, 1996. 44p. (Policy Research Working Paper, n.1667)

WORKING, $\mathrm{H}$. The theory of price of storage. The American Economic Review, v.39, n.6, p.1254-1262, Dec.1949.

WORKING, H. Futures trading and hedging. The American Economic Review, v.43, n.3, p.314-343, 1953.

WORKING, H. Whose markets? evidence on some aspects of futures trading. Journal of Marketing, v.19, p.1-11, 1954. 


\begin{abstract}
ANEXO

\section{Teste de Raiz Unitária}

Uma série temporal é dita estacioanária se sua média, variância e autocovariância são independentes do tempo. Variáveis que apresentam média e variância mudando ao longo do tempo são ditas não estacionárias (Rao, 1994). O problema de regressão espúria surge, de acordo com o esse autor, quando a média e a variância da variável com raiz unitária muda ao longo do tempo, de forma que os valores computados na análise de regressão, que utiliza essa média e variância, ficam também dependente do fator tempo e assim os estimadores falham ao convergir para os verdadeiros valores quando o tamanho da amostra aumenta.
\end{abstract}

O teste da estacionariedade desenvolvido por Fuller (1976), citado por Rao (1994), assume que todos os componentes determinísticos são extraídos antes de proceder à análise do componente estocástico das séries. Tais séries são denominadas homogêneas (ou seja, são não estacionárias em função apenas do componente estocástico). Somente séries dessa natureza podem tomar-se estacionárias, eliminando o problema da raiz unitária pela diferenciação.

Uma forma simplificada, exposta por Gujarati (1995), de apresentar os conceitos implícitos ao testes da existência de raíz unitária das séries temporais pode ser feita empregando um modelo de auto regresssivo simples $\mathrm{AR}(1)$ dado por:

$y_{t}=\alpha y_{t-1}+u_{t}$

onde:

$y_{t}=$ série a ser testada;

$u_{t}=$ processo ruído branco, com média zero e variância constante.

Nessa relação, se $\alpha<1$, tem-se que $y_{t}$ caracteriza-se como um processo estacionário. Se $\alpha=1$, considera-se $y_{t}$ como um processo integrado que não tende a 
convergir a um patamar de longo-prazo ao longo do tempo. A ordem de integração de uma variável diz respeito ao número de vezes que a série deve ser diferenciada em função do número de raízes unitárias (tomando-se diferenças do tipo $y_{t}-y_{t-1}$ ), de forma a tornar-se estacionária.

O teste para raízes unitárias a ser utilizado no presente trabalho será o de DickeyFuller Aumentado, que se refere a um teste da significância estatística de $\alpha$ em regressões estimadas por MQO. Gujarati (1995) afirma que esse procedimento consiste em testar a hipótese nula de que $\alpha=1$ através da tradicional estatística $t$ de student, conhecida como estatística $\tau$ (tau), a qual os valores críticos foram tabulados por Dickey e Fuller. Se a hipótese nula for rejeitada a série é estacionária. Portanto, se o valor computado da estatística $\tau$ exceder o valor crítico (Dickey-Fuller), não rejeita-se a hipótese de que a série é estacionária. Por outro lado, se o valor computado $(\tau)$ for menor do que o valor crítico, a série é não estacionária.

No presente trabalho, foi seguido procedimento proposto por Rao (1994), para o teste de estacioanariedade das séries, o que compreende em testar o modelo apresentado na equação (35), acrescido de constante, e acrescido de constante e tendência, sendo que dessa forma as estatísticas equivanlentes a esses modelos passam a ser respecivamente $\left(\tau_{\mu}\right)$ e $\left(\tau_{\tau}\right)$. 